\title{
Jeofizik Yöntemler ile Yer ve Yapı Etkileşimi
}

\author{
Erkan ATEŞ ${ }^{* 1}$, Osman UYANIK ${ }^{2}$ \\ ${ }^{1}$ AFAD, Deprem Dairesi Başkanlığı, Ankara \\ (ORCID: https://orcid.org/0000-0002-5646-9778) \\ ${ }^{2}$ Süleyman Demirel Üniversitesi, Mühendislik Fakültesi, Jeofizik Mühendisliği Bölümü, 32260, Isparta \\ (ORCID: https://orcid.org/0000-0002-7089-4340)
}

(Alınış / Received: 05.06.2018, Kabul / Accepted: 01.02.2019, Online Yayınlanma / Published Online: 11.03.2019)

\section{Anahtar Kelimeler \\ Deprem, \\ Büyütme, \\ İvmeölçer, \\ Spektral oran, \\ Yer baskın periyod, \\ Girişim}

\begin{abstract}
Özet: Bu çalışmada 5 katlı bir yapının ve yerin deprem dalgalarını büyütme etkisi ve baskın frekansları araştırılmıştır. Bu amaçla 2008 yılında 5 katlı yapının çatısına ve yapının inşa edildiği yere ivmeölçer aygıtları yerleştirilmiştir. Yer sınıfının belirlenmesi amacıyla MASW ölçüsü alınmış, yerin ilk $30 \mathrm{~m}$ için makaslama (kayma) dalgası hızı $\left(\mathrm{Vs}_{30}\right)$ hesaplanmıştır. Bina ve yere yerleştirilen ivmeölçerler kullanılarak moment büyüklügü 3, 4, 5 ve 6 olan, farklı kaynaklardan yakın ve uzak mesafede birçok deprem kaydedilmiştir. Yapının ve yerin büyütmesini elde edebilmek için kaydedilen deprem sinyallerine referans yöntemine göre spektral oran ve tek istasyon yöntemine göre yatay/düşey oran teknikleri uygulanmıştır. $\mathrm{Bu}$ tekniklerin uygulanması sonucunda binaya ve yere ait büyütmeler, baskın frekanslar ve binanın sönüm oranı belirlenmiş, bina ve yerin girişim durumu incelenmiştir. Sonuç olarak yerden binaya geçen deprem dalgalarının genlik büyütmesi deprem büyüklügüne ve uzaklığına bağlı olarak 6-12 aralıkta elde edilmiştir.
\end{abstract}

\section{Ground and Structural Interaction Using Geophysical Methods}

\section{Keywords}

Earthquake,

Amplification,

Accelerometer,

Spectral ratio,

Ground dominant period, Resonance

\begin{abstract}
In this study, it was investigated the amplification effect and dominant frequencies of the earthquake waves, in the 5-floors building and the ground where was built it. With this purpose, accelerometers were placed on the roof and ground of the 5-floors building in 2008. In order to determine the ground class, the MASW measure was taken, shear wave velocity $\left(\mathrm{V}_{\mathrm{s} 30}\right)$ was calculated for the first $30 \mathrm{~m}$. Accelerometers that were placed in the building and the ground recorded earthquakes with moment magnitude of 3, 4, 5 and 6 at close and far distances from different sources. Spectral ratio technique and horizontal / vertical spectral ratio technique have been applied to earthquake signals depending on the reference method and single station method in order to obtain the amplification of the building and the ground. As a result of the application of these techniques, the resonance conditions, the dominant frequencies, and the amplifications which belong to building and ground were investigated. As a result, amplitude amplification of the earthquake waves passing from the ground to the building depending on the earthquake magnitude and distance was obtained between 6 and 12 .
\end{abstract}

\section{Giriş}

Bir deprem meydana geldiğinde kaynaktan yayılan sismik dalgalar yollarının bir bölümünü sert kaya içinde son aşaması ise kayaya göre yumuşak olan yer tabakaları içerisinde geçirirler. $\mathrm{Bu}$ dalgalar yeryüzünde birkaç saniyeden dakikalara varan sürelerde titreşim üretirler. $\mathrm{Bu}$ titreșim süresi depremin büyüklüğüne, merkez üssüne olan uzaklığına ve yer özeliklerine bağlı olarak değişir. Yer hareketinin davranışı, kuvvetli yer hareketi (ivmeölçer) kayıtlarının incelenebilmesi ile mümkündür. Alüvyon bir yeraltı yapısında ilerleyen bir dalganın genliği, sert kaya birimlerine oranla daha büyük olacak ve yer hareketi yumuşak birimlerde daha fazla hissedilecektir.

Sismik dalgalar yer yüzeyine ulaştıklarında bazı frekans içeriğindeki dalgaları bastırırken bazı frekanstaki dalgaların genliklerinin artırmaktadır. $\mathrm{Bu}$ 
genlik artışı yer büyütmesi veya yer etkisi olarak adlandırılmaktadır. $\mathrm{Bu}$ etkinin yumuşak yer özelliklerine sahip alanlarda oluşan hasarlarda büyük etkileri olduğu 1995 Kobe depremi gibi büyük deprem verilerinin incelenmesiyle kanıtlanmıștır [1].

Yer büyütmesinin belirlenmesin de en geçerli yol deprem (kuvvetli yer hareketi) kayıtları analizlerinin kullanılmasıdır. Yer etkisi deprem kayıtları üzerinde bazı yaklaşımlar yapılarak görülebilir. Bunlardan birincisi Standart Spektral Oran (SSR) yöntemidir [2]. $\mathrm{Bu}$ yöntemdeki temel esas yer etkisi belirlenecek deprem istasyonundaki kayıtların yakın bir noktadaki kaya üzerindeki istasyon kaydına oranlanmasıdır. Yer etkisinin hesaplanabilmesi kaynak etkisinin her iki kuvvetli yer hareketi istasyonu için aynı olması gerekmektedir. İstasyonlar arası uzaklığın deprem merkez üssüne olan uzaklığından az olmalıdır [3]. Yer etkisinin bulunmasında kullanılan bir diğer yöntem ise yatay/düşey spektral oran (HVSR) yöntemidir [4,5]. $\mathrm{Bu}$ yöntem düşey bileşenin yer koşullarından etkilenmediği varsayımından yola çıkarak yatay bileșen spektrumlarının düşey bileşene oranlanması prensibine dayanır. Bu yöntem referans istasyonu gerektirmemesi nedeniyle daha kullanışlıdır.

Ülkemizde gerçek deprem kayıtları kullanılarak yer etkisinin belirlenebilmesi için 1995 Dinar depreminden sonra kurulan artçı deprem istasyonlarının analizleri [6] ve İzmir ilinde kurulu bulunan kuvvetli yer hareketi istasyon kayıtları kullanılarak [7] yer etkisi hesaplanmaya çalışılmıştır.

Deprem sırasında yapıda meydana gelebilecek hasar oluşma olasıllğının belirlenebilmesi için beton dayanımı, donatı durumu, temel tipi, kısa kolon gibi yapı parametrelerinin yanı sıra yerin dinamik özelliklerinin belirlenmesi gereklidir [8,9,10,11,12]. Tüm bu parametrelerin dışında yer ve yapı periyodu da belirlenmelidir. Yer baskın salınım periyodu ile yapı salınım periyodunun aynı veya birbirine yakın olması durumunda yapı ile yer arasında girişim (rezonans) oluşması ve buna bağlı olarak hasar oluşma olasılığı bulunmaktadır. Birçok araştırmacı tarafından yapılan çalışmalarda gürültü kayıtlarının analizleri ile yer etkilerinin yanında bina periyodlarını hesaplayarak yer ve bina arasında bir girişim durumunu ortaya koymaya çalışmışlardır $[13,14,15,16,17,18]$. Ancak bu çalışmalar gürültü kayıtları kullanılarak yapılan çalışmalardır. Bu çalışmada ise yapıda ve yerde gerçek deprem kayıtları kullanılarak girișim durumu araştırılmıştır. $\mathrm{Bu}$ çalışmanın diğer çalışmalardan farkı, bina çatı katında ve inşa edildiği yerde kurulan birer adet(toplam 2 adet) ivmeölçer aygıtının kaydettiği gerçek deprem kayıtları ile bina, yer özelliklerini ve girişim durumunu incelemesidir. Ülkemizde yer özelliklerinin belirlenmesi bakımından gerçek deprem kayıtları kullanılmasına karşın, yapıda daha çok gürültü kayıtlarının analizleri kullanılmaktadır.
Bu çalışmada gerçek deprem kayıtları kullanılarak yapı özelliklerinin belirlenmesi özelliğiyle diğer çalışmalardan farklı bir yaklaşım ortaya konulmuştur.

Bu amaç ile Kuzey Anadolu Fay zonu üzerinde yer alan ve birçok önemli depremlere maruz kalan Kocaeli ilinde yer ve bina özelliklerini araştırmak için, Kocaeli Büyükșehir Belediyesi hizmet binası çatı katına ve inşa edildiği yere ivmeölçer cihazları yerleştirilmiştir. Bu cihazların kaydettiği 16 adet deprem, standart spektral oran (SSR) ile yatay/düşey spektral oran (HVSR) yöntemleri kullanılarak değerlendirilmiş, yer ve yapının baskın salınım frekansları, büyütme değerleri, yapı sönüm oranı bulunmuş, yer ve yapı arasındaki bir girișim durumu incelenmeye çalışılmıştır. Gerçek deprem kayıtlarının analizlerinin yanında kuvvetli yer hareketi istasyonunun yer sinıfinın belirlenmesi amacıyla Yüzey dalgalarının çok kanallı analizi (MASW) yöntemi uygulanmış ve ilk 30 m kayma dalga hızı ve yer baskın salınım periyodu hesaplanmıștır. Deprem kayıtlarının SSR, HVSR analizlerinden ve MASW'dan elde edilen yerin baskın salınım periyodları karşılaştırılmıştır.

\section{2. Çalıșma Alanı ve Kullanılan Yöntemler}

\section{1. Çalışma alanının tanıtımı}

Marmara bölgesinin üçüncü büyük ili olan Kocaeli Kuzey Anadolu Fay (KAF) üzerinde yer almakta olup bu fay zonunda meydana gelen depremlerden etkilenmektedir.

Kocaeli il merkezine $12 \mathrm{~km}$ uzağında KAF üzerinde 17 Ağustos 1999 tarihinde yerel saat ile 03:02'de meydana gelen moment büyüklüğü 7.4 olarak hesaplanan deprem meydana gelmiștir. Depremin merkez üssü ve derinliği mülga Bayındırlık ve İskan Bakanlığı Deprem Araștırma Dairesi tarafından hesaplanmıştır.

1999 yılında meydana gelen depremde Kocaeli ili genelinde 31.625 konut ağır, 29076 konut orta, 31.751 konut hafif hasara sebep olmuştur [19].

Kocaeli il ve ilçe merkezlerindeki konutların hasar durumlarına yüzde olarak bakacak olursak, Kocaeli il merkezinin \% 10'u, Gebze \% 0.48'i, Gölcük \% 35.70'i, Kandıra \% 0.25'i, Karamürsel \% 14.19'u ve Körfez \% 12.75 'i ağır hasara uğramıştır [14]. Görüleceği üzere depremde en yüksek hasar Gölcük ilçe merkezinde oluşmuştur. Hasar durumundan da anlaşılacağı üzere 17 Ağustos 1999 tarihinde Kocaeli ilinde etkili olan depremden sonra, kent dokusunda ciddi bir dönüșüm ve değişim gerçekleşmiştir.

Deprem sonrası Kocaeli Büyükşehir Belediyesi tarafında Kocaeli ili mikro bölgeleme etüt işlemleri tamamlanmıştır. Ayrıca deprem anında hasar 
yapabilen kuvvetlerin belirlenmesi amacıyla Kocaeli Büyükşehir Belediyesi ve AFAD Deprem Dairesi Başkanlığının işbirliği ile Kocaeli.NET yerel ivmeölçer deprem istasyon ağı kurulmuştur. Olası bir depremde yapı sağlı̆̆ının izlenmesi ve yapıya gelecek deprem kuvvetin belirlenmesi amacıyla 2008 yılında Kocaeli Belediyesi Hizmet binasının çatı katına bir adet ve binanın inşa edildiği yere bir adet olmak üzere 2 adet ivmeölçer aygitları kurulmuştur. Çalışma konusu olan bina Şekil 1'de gösterilmiştir.

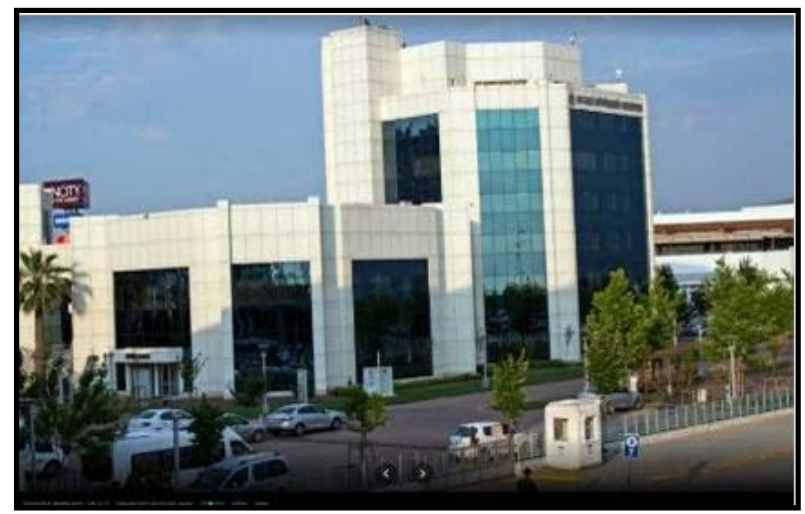

Şekil 1. Çalışma konusu bina

\subsection{Yüzey dalgalarının çok kanallı analizi yöntemi (MASW)}

Yüzey dalgalarının çok kanallı analizi ilk olarak $[20,21,22]$ tarafından ortaya atıldı. Kaynağı aktif olan MASW tekniği [23] tarafından geliştirildi. Bilindiği üzere yüzey dalgalarının önemli bir fiziksel özelliği dispersiyondur. Yüzey dalgalarının dispersiyon eğrisinin analizinden ortama ait kayma dalga hızları elde edilir [24]. Kayma dalga hızının elde edilme aşamaları Şekil 2' de verilmiştir

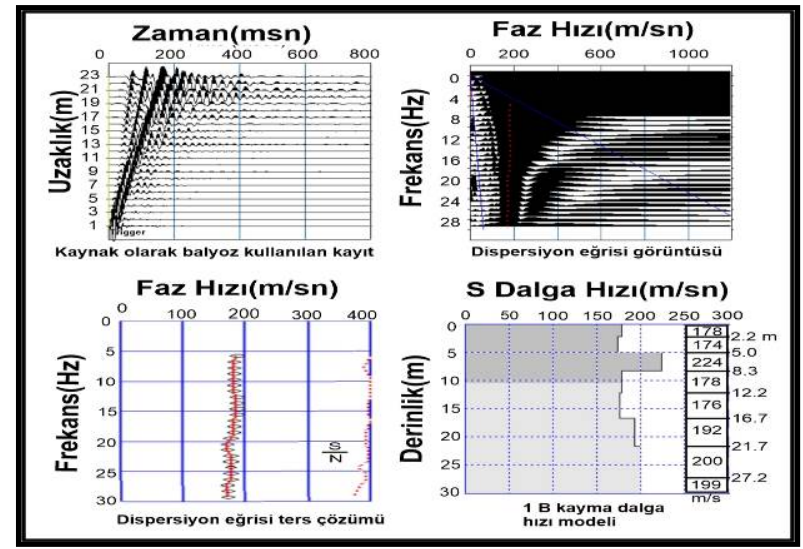

Şekil 2. Çok kanallı yüzey dalgalarının analizi[25]

Çalışma alanlarında yorumlanabilir nitelikte veri toplamak için yöntemin kuramına uygun olarak ölçüm yapmak gerekmektedir. Bu amaçla MASW yönteminde uygun veri toplamak için kaynakta yeterli miktarda enerjinin oluşturulması ve verilerin elde edilmesi için uygun frekanslı $(4.5 \mathrm{~Hz}, 2 \mathrm{~Hz})$ jeofonların kullanılması gereklidir. MASW yönteminde kayıt olağan sismik kırılma yönteminde olduğu şekilde alınır. Kaynak noktası (Ofset) mesafesi ve $4.5 \mathrm{~Hz}$ lik jeofonlar ile oluşturulan serimin aralıkları çalışma amacına göre seçilir. Gürültünün bastırılması ve sinyallerin daha belirgin hale gelmesi amacıyla vuruş aynı noktada birkaç kez tekrarlanarak yığma işlemi yapılabilir. Yer içinde ilerleyen rayleigh dalgası yüzeydeki jeofonlar yardımıyla kayıt altına alınır.

Kaydedilen MASW verisine ilk olarak faz hızı-frekans dönüşümü uygulanır. Bu işlem sonucu dalganın dispersiyon eğrisi hesaplanarak görüntülenir. Ölçülen veri ile yeraltının kuramsal modelinin dispersiyon eğrileri birbiri ile çakışana kadar hesaplama yapılır. $\mathrm{Bu}$ işleme ters çözümü denir. Ters çözüm işleminden sonra yeraltının derinliklerine göre değișen bir boyutlu kayma dalga hız modeli oluşur (Şekil 2).

MASW çalışmasından derine doğru elde edilen kayma dalga hızları kullanılarak Yer baskın salınım periyodu eşitlik 1 den hesaplanır. Eşitlik 1 deki $\mathrm{H}$ derinliği kayma dalga hızına bağlı 30 ya da $50 \mathrm{~m}$ seçilir. $\mathrm{Bu}$ seçim ilk $30 \mathrm{~m}$ içerisinde $\mathrm{V}_{\mathrm{S}}>500 \mathrm{~m} / \mathrm{s}$ elde edilir ise $\mathrm{H}=30 \mathrm{~m}$ alınır tersi olması durumunda $\mathrm{H}=50 \mathrm{~m}$ kullanılmalıdır [26].

$$
\mathrm{Tz}=\frac{4 h_{1}}{V_{S 1}}+\frac{4 h_{2}}{V_{S 2}}+\frac{4\left(H-\left(h_{1}+h_{2}\right)\right)}{V_{S 3}}
$$

\subsection{Kuvvetli yer hareketi ölçümleri}

Yapının inşa edildiği yerde meydana gelebilecek yatay ivmenin tahmini ve depremin uzaklıkla olan azalım ilişkisinin geliştirilmesi ile depreme dayanıklı yapı tasarımları yapılabilir. Mühendislik açısından öneme sahip olan yer hareketlerinin özelliklerini ve bu özellikleri yansıtan yer hareketi parametrelerini tanımlamak gerekmektedir. Yer hareketi parametrelerinin tanımlanması ve değerlendirilmesi için gerçek depremler sırasında ölçülmüş ivmeölçer kayıtlarının incelenmesi gerekir. Yapı sağlı̆̆ izlenmesi amacıyla kurulacak ivmeölçer kayıtçıları yapının bir deprem anında salınımını, davranışını belirlemek ve büyük bir deprem sonrasında yapının olası hasar alma durumunu tespit etmek amaciyla kullanılır. Yapı sağlığı izleme sistemlerinin yeni deprem yönetmeliğinde yüksek yapılara kurulması zorunluluğu getirilmiştir.

Kuvvetli yer hareketinin süresinin deprem hasarı üzerindeki etkisi çok güçlü olabilir. Genliği yüksek fakat süresi kısa bir hareket yapıda hasar yapıcı bir etki yaratmayacak ancak orta düzeyde genlikli ve uzun süreli bir hareket, yapıda önemli derecede yıkıcı hasara neden olabilmektedir.

\subsubsection{Yatay düşey spektral oran yöntemi (HVSR)}

Yöntemin esası; tek istasyonda kaydedilen deprem dalgalarının S fazlarının Yatay (H) genlik spektrumlarının Düşey (V) genlik spektrumuna oranlanmasına dayanır $[4,5]$. 
Deprem kayıtlarında düşey bileşenlerin yer tabakalarının özelliklerinden etkilenmediği buna karşın yatay bileşenlerin, tabakaların hız ve yoğunluk özelliklerine göre deprem dalgalarının genliklerini belli frekanslarda büyütmeye uğratırlar. Bu teoriye göre büyütmeye uğrayan yatay bileşen spektrumlarının düşey spektruma oranlanması ile yer/yapı transfer fonksiyonunun elde edilmesi sağlanır. Özetle yöntem düşey bileşeni referans bileşen olarak kullanmaktadır.

$$
S_{z}=\frac{S_{t}}{A_{t}}=\frac{\frac{H_{s}}{H_{b}}}{\frac{V_{s}}{V_{b}}}=\frac{H_{s}}{V_{s}}
$$

Eşitlik 2 de verilen Hs yatay bileşen spektrumlarını Vs düșey bileșen spektrumunu $\mathrm{Sz}$ ise transfer fonksiyonunu temsil eder.

\subsubsection{Standart spektral oran yöntemi}

Standart spektral oran yöntem ilk olarak [2] tarafından kuvvetli yer hareketi kayıtlarına uygulanmıștır. Zayıf ve kuvvetli yer hareketi istasyon kayıtlarına uygulanan yöntem, 1970 yılından günümüze yaygın olarak kullanılmaktadır [2].

- Mikrotremor veya kuvvetli yer hareketi kayıtlarının yatay bileșenlerin S dalgasının bir kısmı pencere ile çlkarılır.

- Çıkarılan yatay bileşen penceresinin yuvarlatılmış hızlı Fourier (FFT) genlik spektrumu alınır.

- Büyütmesi hesaplanacak noktadaki yatay bileșen yuvarlatılmış Fourier genlik spektrumu, referans olarak kullanılacak istasyona ait yatay bileşen yuvarlatılmış Fourier genlik spektrumuna oranlanarak transfer fonksiyonu (TF) hesaplanmış olur.

$$
\operatorname{Tf}(f)=\operatorname{Hs}(f) \div \operatorname{Hr}(f)
$$

ile tanımlanır. Eşitlik 3'te $\mathrm{H}_{\mathrm{s}}(\mathrm{f})$ alüvyon noktasına ait yatay bileşen Fourier genlik spektrumu, $\mathrm{H}_{\mathrm{R}}(\mathrm{f})$ referans noktasına ait yatay bileşen Fourier genlik spektrumunu gösterir.

\section{Bulgular}

\subsection{MASW sonuçları}

Kocaeli belediyesi hizmet binası bahçesinde bulunan ivmeölçer istasyonunun yer sınıfının belirlenmesi amacıyla MASW ölçüsü alınmıştır. Sismik saha çalışması için kaynak, kablo, jeofon ve kayıt sistemlerinden oluşan bütünleşmiş bir sistem kullanılmıştır. Enerji kaynağı olarak 50 kg ağırlıklı elektromekanik bir kaynak sistemi kayıt aygıtı olarak 48 kanallı (2 adet 24 kanall sistem) Geode marka sismik kayıt aygıtı kullanılmıştır. Ölçü alımlarında jeofon aralıkları ve ofset $2 \mathrm{~m}$, serim uzunluğu $96 \mathrm{~m}$ olup, 48 adet $4.5 \mathrm{~Hz}$ düșey jeofonlar kullanılmıştır. Örnekleme aralığı 1 ms, kayıt uzunluğu 2 sn'dir. Kullanılan aygıtlar şekil 4'te gösterilmiştir.

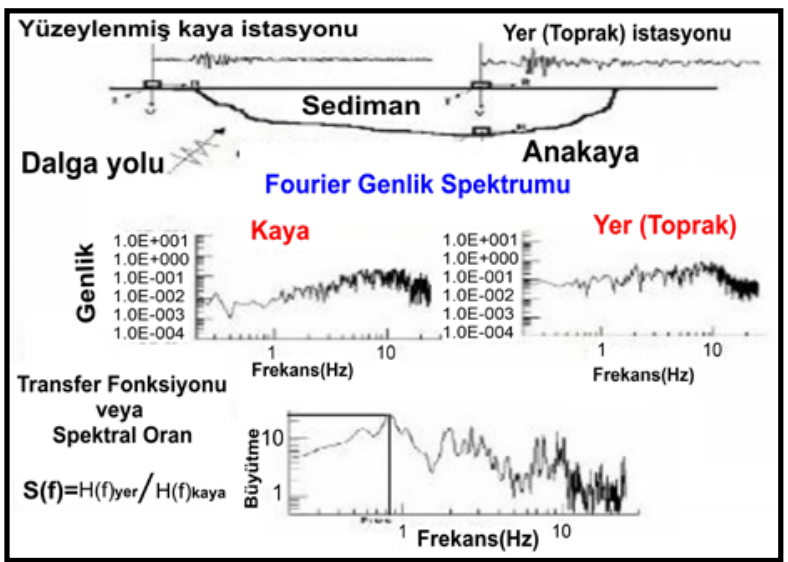

Şekil 3. SSR yöntemi temel veri işlem [27] den düzenlenmiştir.

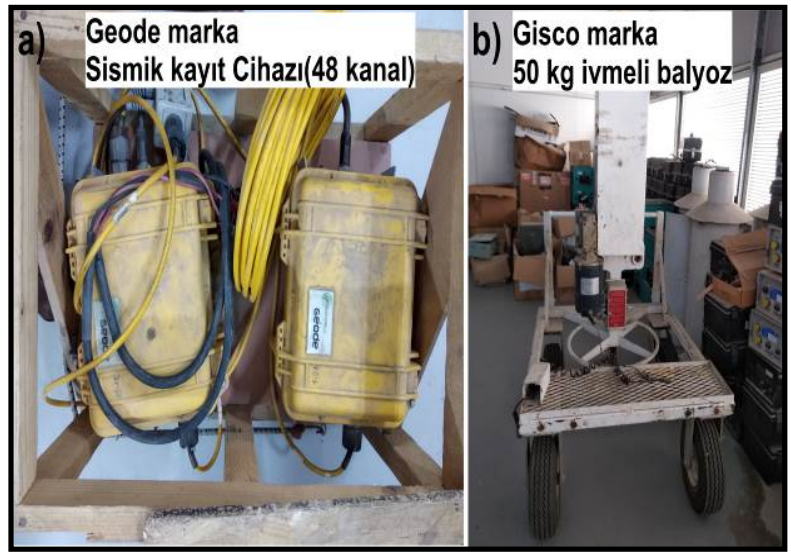

Şekil 4. a) Sismik kayıtçı, b) 50-kg ivmeli balyoz,

Yapılan veri işlem sonrasında oluşan dispersiyon eğrisi Şekil 5'te verilmiş olup veri işlem aşamaları sonucunda yer tabakalarının ilk 30 m kayma dalgası hızı $148 \mathrm{~m} / \mathrm{s}$ (şekil 5b) bulunmuştur. İstasyon bulunduğu yerde 2013 yılında yapılan SPAC ölçümü sonucu bu çalışmada gösterilen MASW sonuçlarıyla uyumludur.

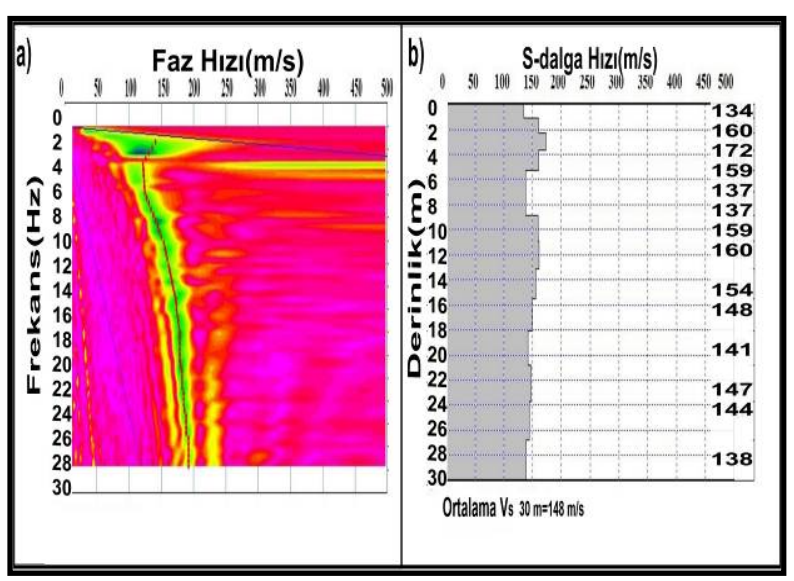

Şekil 5. a) Dispersiyon eğrisi, b)Derinlik hız modeli 
Yer baskın salınım periyodunun 50 m etkinliğe kadar yapılan hesaplamada etkin derinlik $50 \mathrm{~m}$ kadar ulaşamadığı göz önüne alındığında son tabakanın hızının 50 m kadar aynı kaldığı kabulune göre yapılan hesapta baskın salınım periyodu 1.25 sn olarak hesaplanmış, frekansta ise $0.80 \mathrm{~Hz}$ olarak bulunmuştur. Benzer şekilde $\mathrm{Vs}_{30}=148 \mathrm{~m} / \mathrm{s}$ kullanılarak hesaplanan baskın salınım periyot 1.23 sn elde edilmiştir.

\subsection{Deprem (ivme) kayıtlarının analizleri}

\subsubsection{Standart spektral oran yöntemi sonuçları}

Standart spektral oran (SSR) yönteminde bir depremde dinamik özellikleri hesaplanması istenilen kayıtçının yatay bileşenlerinin spektrumunun referans istasyonun yatay bileşen spektrumuna bölerek yer büyütmesini belirlemektir.

Kocaeli Belediyesinin yapı sağlı̆̆ izlenmesi amacıyla kurulan ivmeölçer istasyonları Şekil 6’da gösterilmiştir

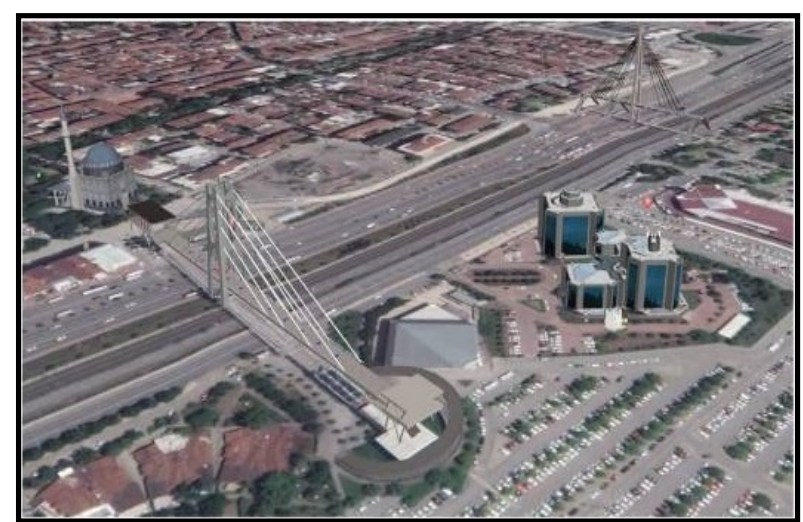

Şekil 6. Bina ve zeminde kurulan istasyonların konumları (Google Earth)

SSR yönteminde yer büyütmesinin belirlenmesi amaciyla referans istasyon olarak Meteoroloji müdürlüğünde bulunan ivmeölçer aygıtı kullanılmıştır. Bina büyütmesinin bulunması amaciyla yerde bulunan istasyon referans istasyon olarak kullanılmıştır. Kaydedilen kayıtlar SSR yöntemi ile değerlendirilmiştir.

Bina büyütmesinin belirlenebilmesi amaciyla 5. Katta bulunan ivmeölçerler tarafından kaydedilen kayıtların yatay bileşenlerin S dalga penceresi FFT'si alınarak birleștirilmiş yerde bulunan kayıtların yatay bileşenlerine oranlanmıştır. Yer büyütmesinin belirlenmesi amaciyla yerde bulunan istasyonun yatay bileşenlerinin $S$ dalga penceresi kayada bulunan ivmeölçer kayıtlarına oranlanmıștır.

Kocaeli Büyükşehir Belediyesi binası ve yer özelliklerini anlamaya yönelik Şekil 6'da konumları gösterilen iki farklı istasyon (bina çatı katı ve yerde bulunan istasyon) tarafindan ortak olarak kayıt edilen farklı büyüklüğe, merkez üssünden farklı uzaklığa sahip 16 adet deprem verisi kullanılmıştır. Kullanılan depremlerin konumları Şekil 7'de moment magnitüdleri ve tarihleri Tablo 1'de gösterilmiștir. Kocaeli Büyükșehir Belediyesi binasının kurulu olduğu yerin büyütmesini belirlemek içinse kayada kurulu olan referans istasyon ile bina bahçesindeki istasyon tarafindan ortak olarak kayıt edilen farklı büyüklüğe, merkez üssünden farklı uzaklığa sahip 5 adet deprem verisi kullanılmış ve bunlar Şekil 8 de ve Tablo 2 de sunulmuştur.

Tablo 1. Bina ve yerde bulunan ivmeölçerlerin kaydettiği ortak depremler

\begin{tabular}{|c|c|c|c|c|c|}
\hline No & Enlem & Boylam & Mw & Tarih & $\begin{array}{c}\text { Uzaklık } \\
\text { (km) }\end{array}$ \\
\hline 1 & 40,817 & 28,1925 & 4,4 & 3.10 .2010 & 147 \\
\hline 2 & 40,734 & 29,7567 & 4,2 & 20.01 .2011 & 15 \\
\hline 3 & 40,137 & 29,9643 & 4,7 & 11.07 .2011 & 69 \\
\hline 4 & 39,1328 & 29,082 & 6,2 & 19.05 .2011 & 195 \\
\hline 5 & 40,8195 & 27,7498 & 5,3 & 25.07 .2011 & 184 \\
\hline 6 & 40,7608 & 30,4077 & 3,6 & 7.07 .2012 & 40 \\
\hline 7 & 39,6553 & 25,5912 & 5,6 & 8.01 .2013 & 386 \\
\hline 8 & 40,7427 & 30,284 & 2,8 & 10.11 .2013 & 30 \\
\hline 9 & 40,7743 & 31,8762 & 4,9 & 24.11 .2013 & 164 \\
\hline 10 & 40,4113 & 30,1001 & 4,5 & 22.10 .2014 & 41 \\
\hline 11 & 39,8775 & 30,3785 & 4,0 & 17.01 .2015 & 105 \\
\hline 12 & 40,2575 & 29,1608 & 4,3 & 7.06 .2016 & 86 \\
\hline 13 & 40,68 & 29,2128 & 4,2 & 25.06 .2016 & 61 \\
\hline 14 & 40,7058 & 30,1288 & 3,5 & 2.09 .2016 & 18 \\
\hline 15 & 38,7358 & 27,8156 & 5,1 & 27.05 .2017 & 286 \\
\hline 16 & 38,8488 & 26,3126 & 6,2 & 12.06 .2017 & 372 \\
\hline
\end{tabular}

Tablo 2. Kaya (referans istasyon) ve yerde (bina bahçesi) bulunan ivmeölçerlerin kaydettiği ortak depremler

\begin{tabular}{|c|c|c|c|c|c|}
\hline No & Enlem & Boylam & Mw & Tarih & $\begin{array}{c}\text { Uzaklık } \\
(\mathbf{k m})\end{array}$ \\
\hline 1 & 40,7427 & 30,284 & 2,8 & 10.11 .2013 & 30 \\
\hline 2 & 40,7743 & 31,8762 & 4,9 & 24.11 .2013 & 164 \\
\hline 3 & 40,5956 & 29,1655 & 4,0 & 03.08 .2014 & 67 \\
\hline 4 & 39,8775 & 30,3785 & 4,0 & 17.01 .2015 & 105 \\
\hline 5 & 41,0000 & 29,0000 & 3,8 & 13.08 .2015 & 54 \\
\hline
\end{tabular}

Veri işlem aşamasında GEOPSY programı kullanılmıştır [28]. Kullanılan kayıtların tümü saniyede 100 örnek olacak şekilde sayısallaştırılmış. Aygit etkileri giderilmiştir. Yer ve yapı üzerinde meydana gelen deprem etkisini hesaplamak için deprem kayıtların yalnızca S dalga fazı kullanılmıştır. $\mathrm{Bu}$ amaçla kullanılan tüm verilerden 5 sn uzunlukta pencereler ile kesilen veriler 0,1-20 Hz BANDPASS süzgeç kullanılmış ve veri uçları $\% 5$ kosinüs pencere ile yuvarlatılmış, FFT kullanılarak genlik spektrumları alınmıştır. İvme kayıtlarının yalnızca yatay bileșenleri spektrumların bileşkeleri alınarak, referans istasyona oranlanmış, baskın frekans ve büyütme değerleri ortaya çıkarılmıştır. 


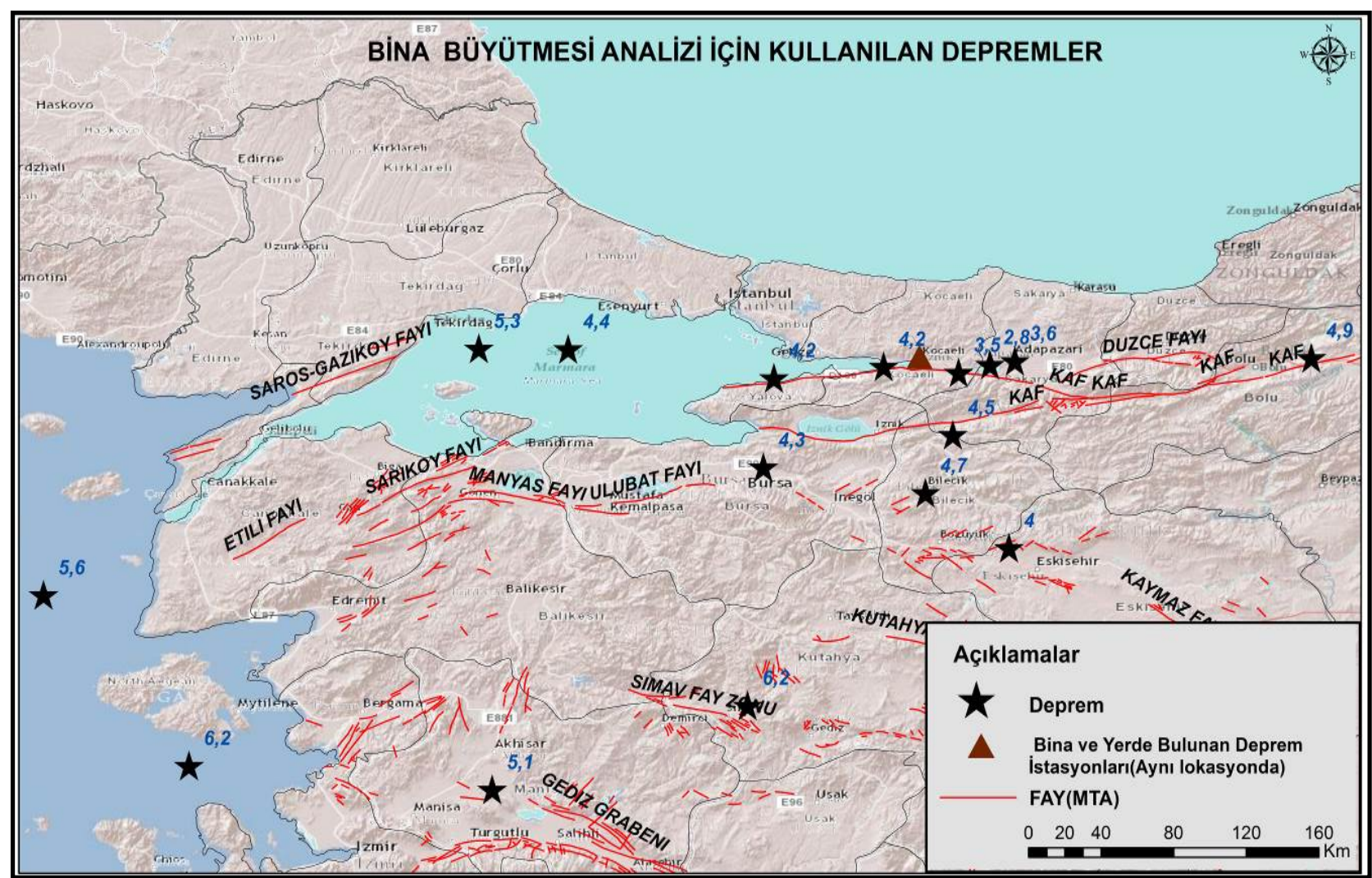

Şekil 7. Bina büyütmesi için kullanılan depremler

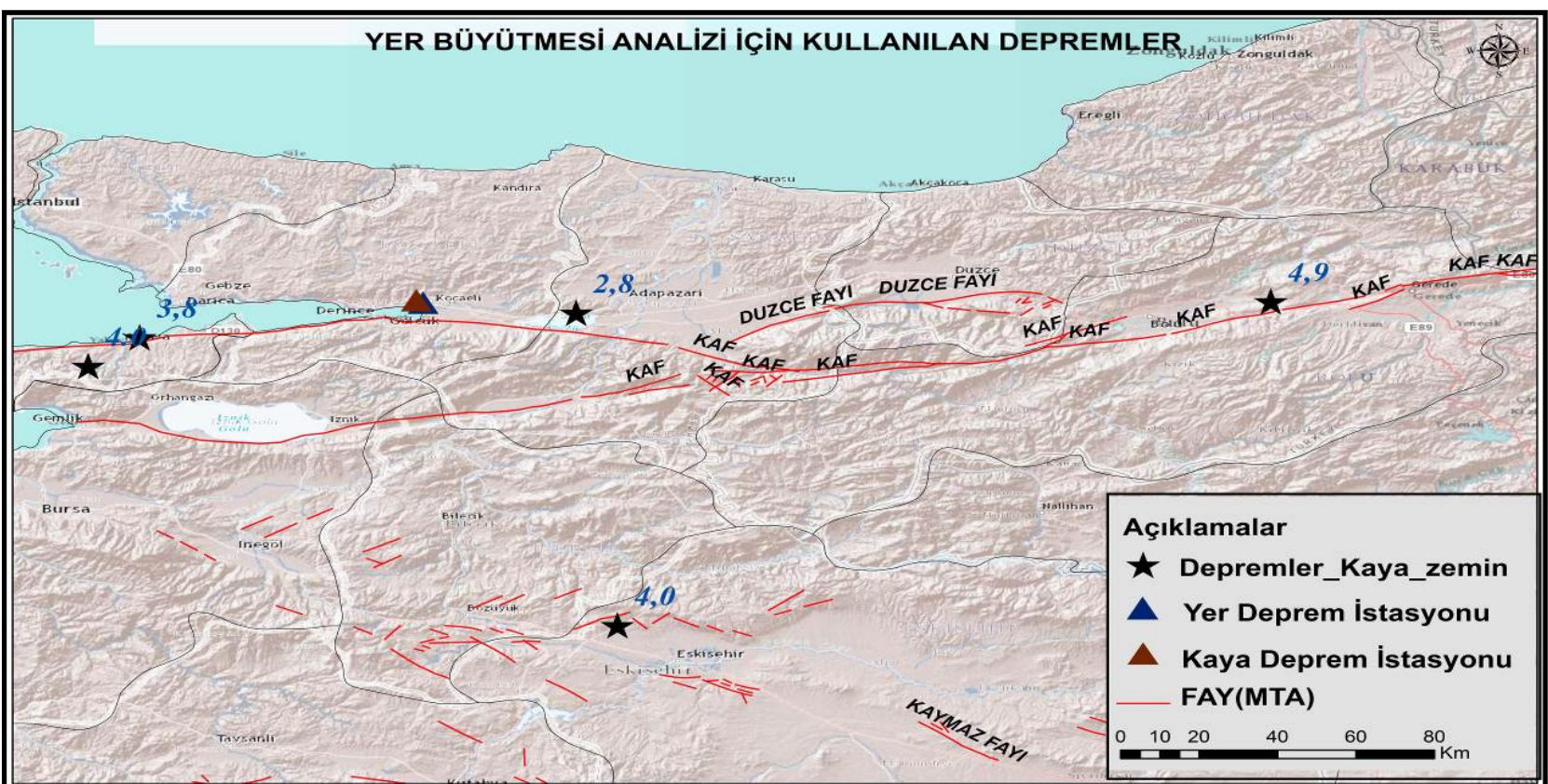

Şekil 8. Yer büyütmesi için kullanılan depremler

Veri işlem aşamaları așağıdaki sırada verilmiștir.

-Eğilim etkisi giderimi

-Süzgeçleme işlemi (Bandpass, 0,1-20 Hz)

- Pencereleme seçimi işlemi

- Kayıtların kenarlarına uygulanan törpüleme işlemi

(taper, \%5)

- FFT

-Yuvarlatma işlemi (Konno ve Ohmachi, b=40) [29]

-Yatay bileşen spektrumlarının oranı (Bina/Yer, Yer/Kaya)

\subsubsection{Bina/Yer SSR yöntemi sonuçları}

Bina baskın frekansı (1. Mod) ve büyütmesini belirlemek için Tablo 1 de verilen farklı büyüklük ve konumlardaki 16 adet depreme ait 32 ivme kaydı kullanılmıştır. Sonuçlardan dört adet örnek depreme ait grafikler Şekil 9 - Şekil 12'de sunulmuştur. Sunuş sırası a) grafiğinde yer ve binada kurulu bulunan ivme kayıtlarında seçilen $\mathrm{S}$ dalga penceresi belirtilmiştir. Kayıtların a) grafiğinde sağ üst köşesinde istasyonun kayıt ettiği en büyük ivme değeri $(\mathrm{PGA}) \mathrm{cm} / \mathrm{s}^{2}$ biriminden verilmiştir. b) 
grafiğinde Seçilen S dalga fazının FFT'si alınarak frekans ortamına geçilmiş ve yön bağımlılığından kurtulmak için iki yatay bileşenin birleștirilmiştir. Yapı büyütmesi ve baskın frekansının bulunması için yer istasyonu referans istasyon olarak düşünülmüş ve bina kaydı yer frekansına oranlanmış ve sonuçlar ayrı ayrı grafiklenmiştir. c) grafiğinde ise kayıtların seçilen S fazının spektrumları iki yatay bileşeni ayrı ayrı sunulmuştur. Şekil 13'de 16 adet deprem verisinin veri işleminden elde edilen bina/yer spektral oran grafikleri elde edilmiştir. Tüm kayıtlarda görüleceği üzere $2 \mathrm{~Hz}$ frekansında ani bir doruk görülmektedir. Binanın baskın salınım frekansı (1.Mod) bu frekans olduğu düşünülmektedir. Şekil 14 'te ise bu 16 deprem kaydının spektral oranının ortalamasını görmekteyiz. Spektral oran yönteminde bina yatay bileșen spektrumunun yer spektrumuna oranlanması sebebiyle bina kayıtlarından yer etkisi giderilmiş ve saf bina transfer fonksiyonu elde edilmiştir.

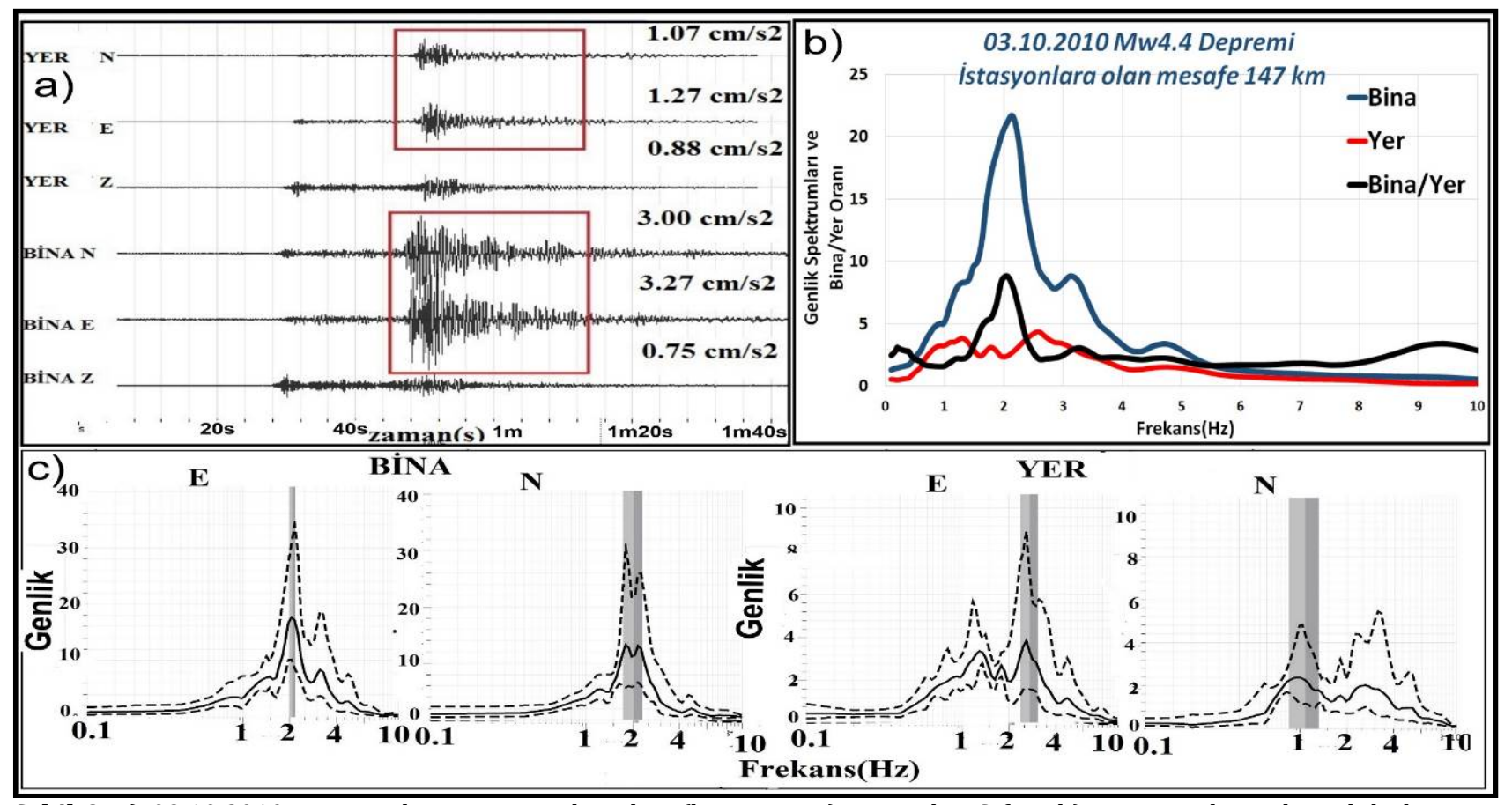

Şekil 9. a) 03.10.2010 Mw 4,4 depremi ivme kayıtları (bina ve yer) ve seçilen S fazı, b) Yatay spektrumların bileşkesi ve bina/yer oranı, c) Bina ve yer yatay bileşen spektrumları

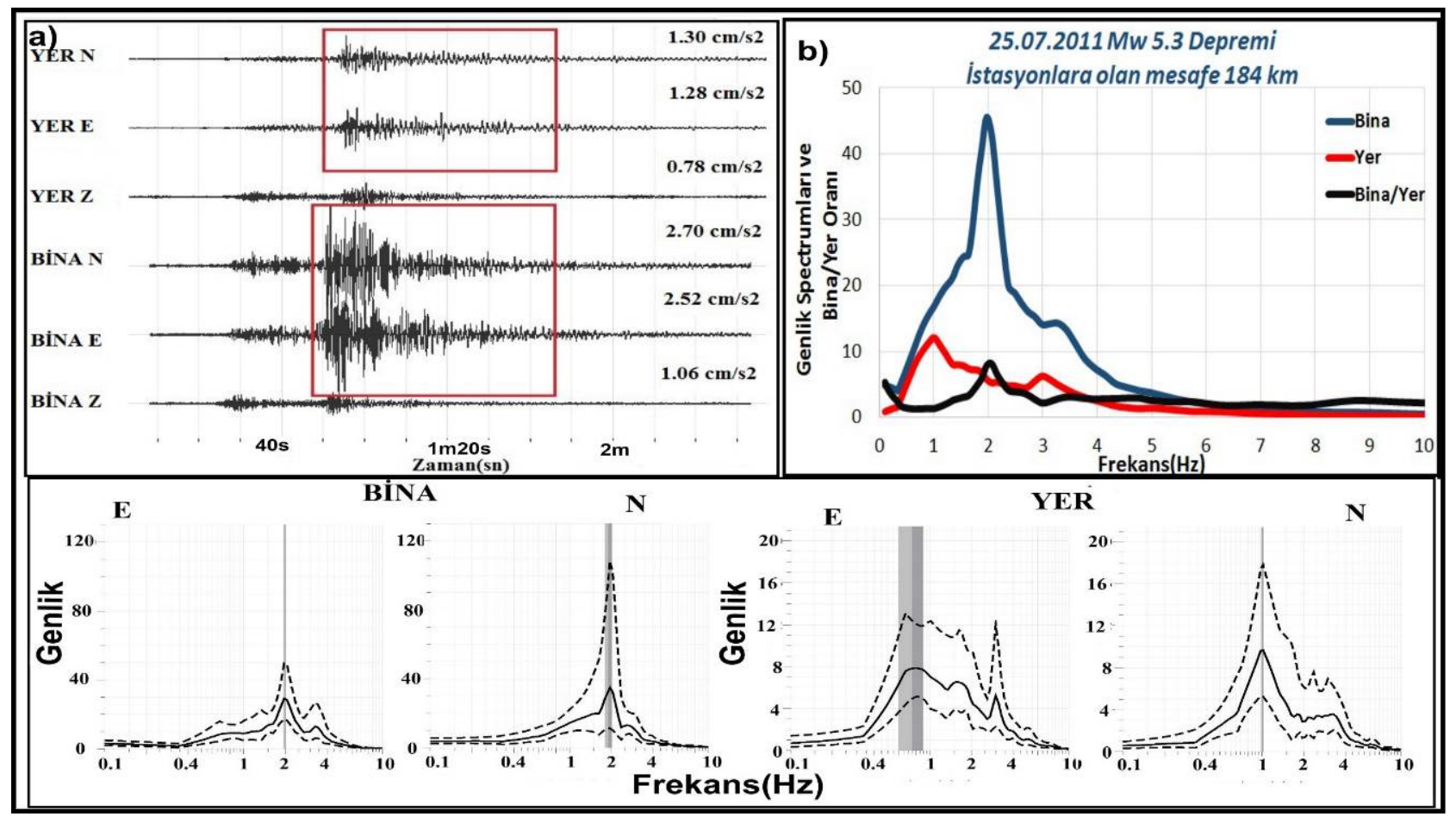

Şekil 10. a) 25.07.2011 Mw 5,3 depremi ivme kayıtları (bina ve yer) ve seçilen S fazı, b) Yatay spektrumların bileşkesi ve bina/yer oranı, c) Bina ve yer yatay bileşen spektrumları 


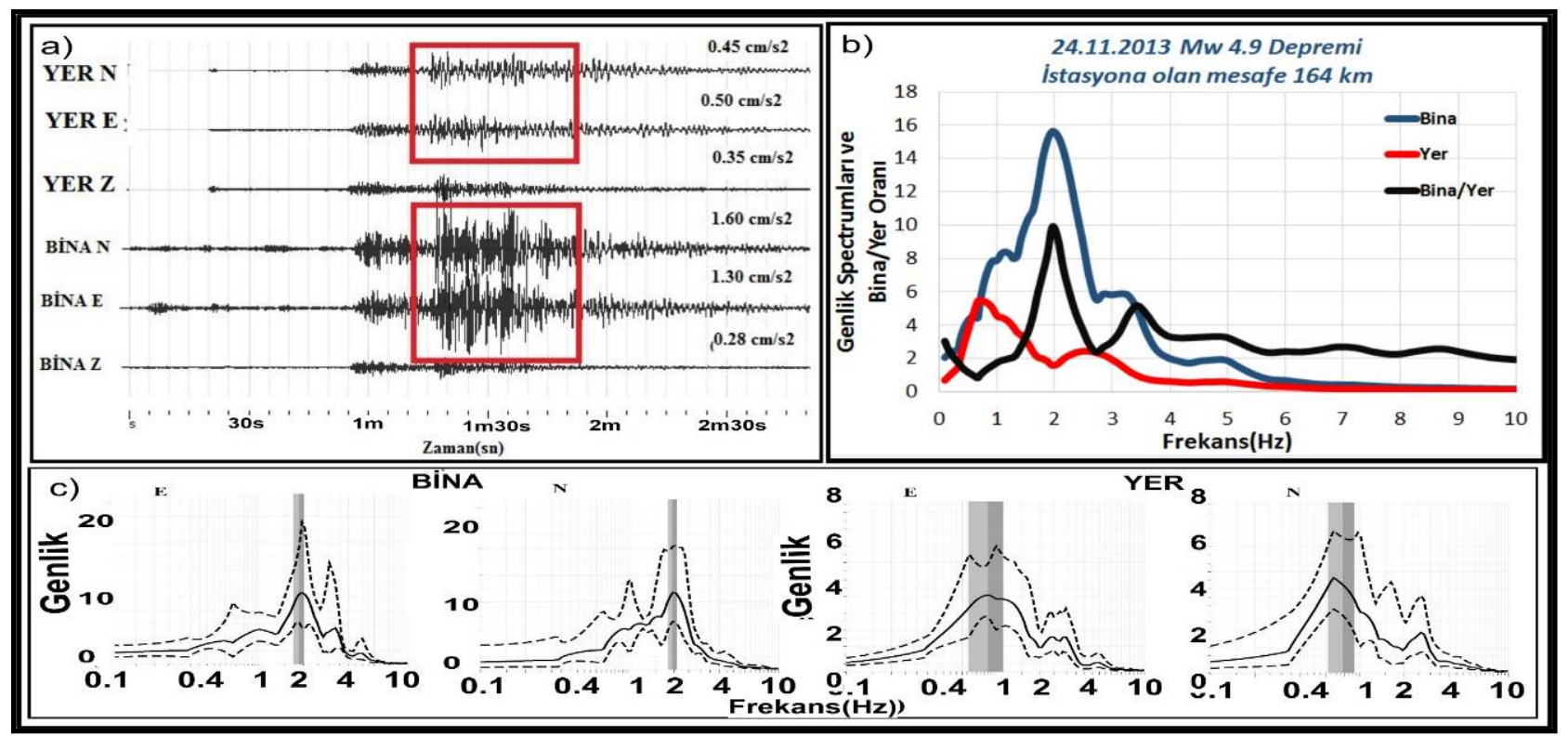

Şekil 11. a) 24.11.2013 Mw4.9 depremi ivme kayıtları (bina ve yer) ve seçilen S fazı, b) Yatay spektrumların bileşkesi ve bina/yer oranı, c) Bina ve yer yatay bileșen spektrumları

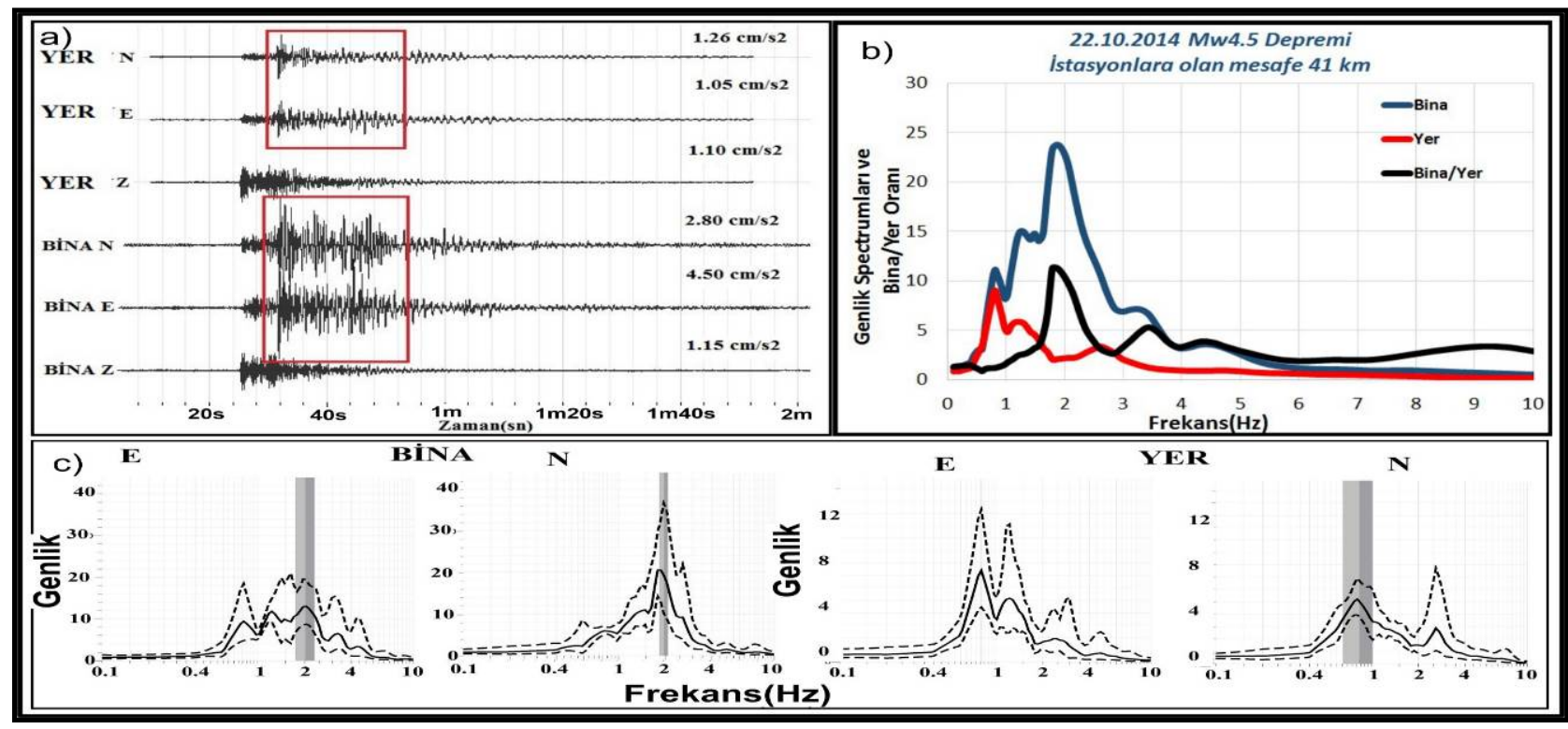

Şekil 12. a) 22.10.2014 Mw 4,5 depremi ivme kayıtları (bina ve yer) ve seçilen S fazı, b) Yatay spektrumların bileșkesi ve bina/yer oranı, c) Bina ve yer yatay bileșen spektrumları

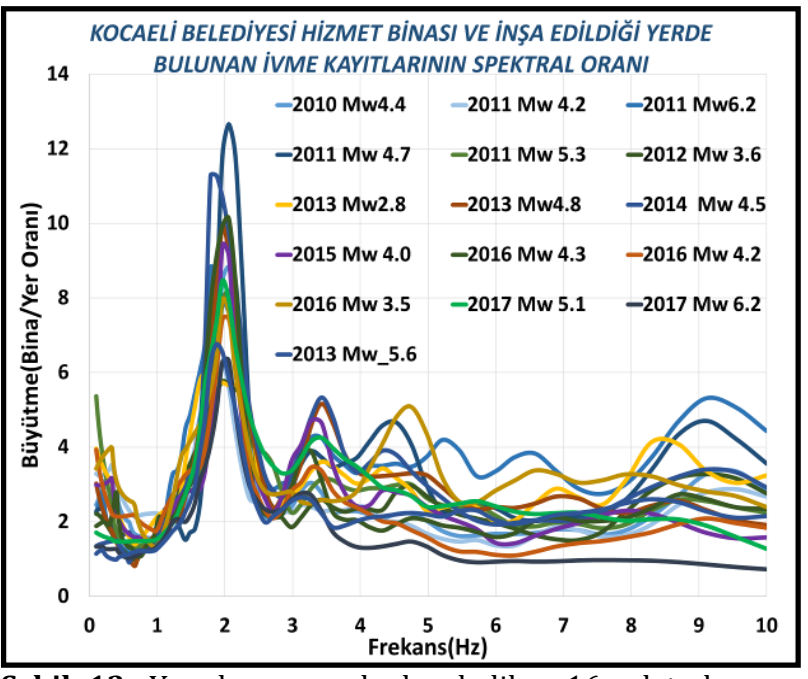

Şekil 13. Yapıda ve yerde kaydedilen 16 adet deprem kaydının spektral oran yöntemi (SSR) büyütme sonuçları

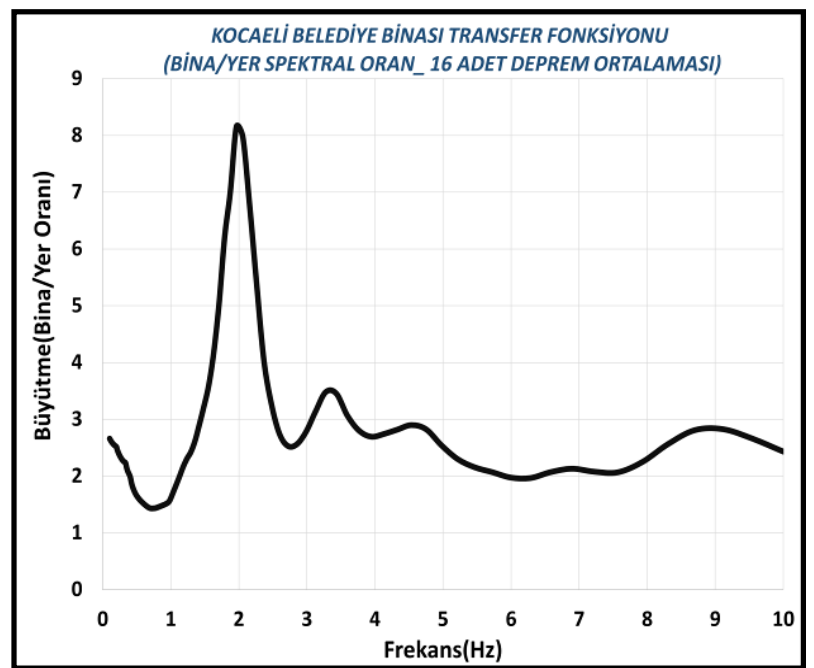

Şekil 14. Bina büyütmesi için SSR Yöntemi sonuçlarının ortalaması 


\subsubsection{Yer/Kaya SSR yöntemi sonuçları}

Yer baskın salınım frekansı ve büyütmesini belirlemek için Tablo 2'de verilen farklı magnitüd ve lokasyonlardaki 5 adet depreme ait 10 ivme kaydı kullanılmıştır. Depremlere ait örnekler Şekil 15 ve şekil 16'te sunulmuştur. Sunuş sırası a grafiğinde yer ve kaya kurulu bulunan ivme kayıtlarında seçilen S dalga penceresi belirtilmiştir. Kayıtların a) grafiğinin sağ üst köşesinde istasyonun kayıt ettiği PGA değerleri $\mathrm{cm} / \mathrm{s}^{2}$ biriminden verilmiştir. b) grafiğinde Seçilen S dalga fazının FFT si alınarak frekans ortamına geçilmiș ve yön bağımlılığından kurtulmak için iki yatay bileşenin birleştirilmiştir. Yer büyütmesi ve baskın frekansının bulunması için kayadaki istasyon referans istasyon olarak düşünülmüș ve yer kaydı kaya frekansına oranlanmış sonuçlar ayrı ayrı grafiklenmiștir. c) grafiğinde ise kayıtların seçilen $\mathrm{S}$ fazının Spektrumları iki yatay bileşeni ayrı ayrı sunulmuştur.

Şekil 17 'de 5 adet depremden elde edilen transfer fonksiyonları bulunmuștur. Șekil 18'de ise bu 5 adet depremin sonucunun ortalaması bulunmaktadır. Spektral oran yönteminde yer baskın salınım frekansı $0,7 \mathrm{~Hz}$ bulunmuştur.

Kullanılan 5 adet deprem ivme kaydının analizleri sonucunda baskın salınım frekans $0.67-0.70 \mathrm{~Hz}$ büyütme oranı ise yaklaşık 6,5 olarak bulunmuştur. Ancak referans olarak kullanılan deprem istasyonunun yüzeylenmiş anakaya olmaması nedeniyle baskın frekansta diğer yöntemlere göre küçükte olsa farklılıklar mevcuttur. Diğer yöntemler ile karşılaştırıldığında referans istasyonun kaliteli olmamasına karşın baskın frekans değeri diğer yöntemlerin sonuçları ile benzerlik göstermektedir.

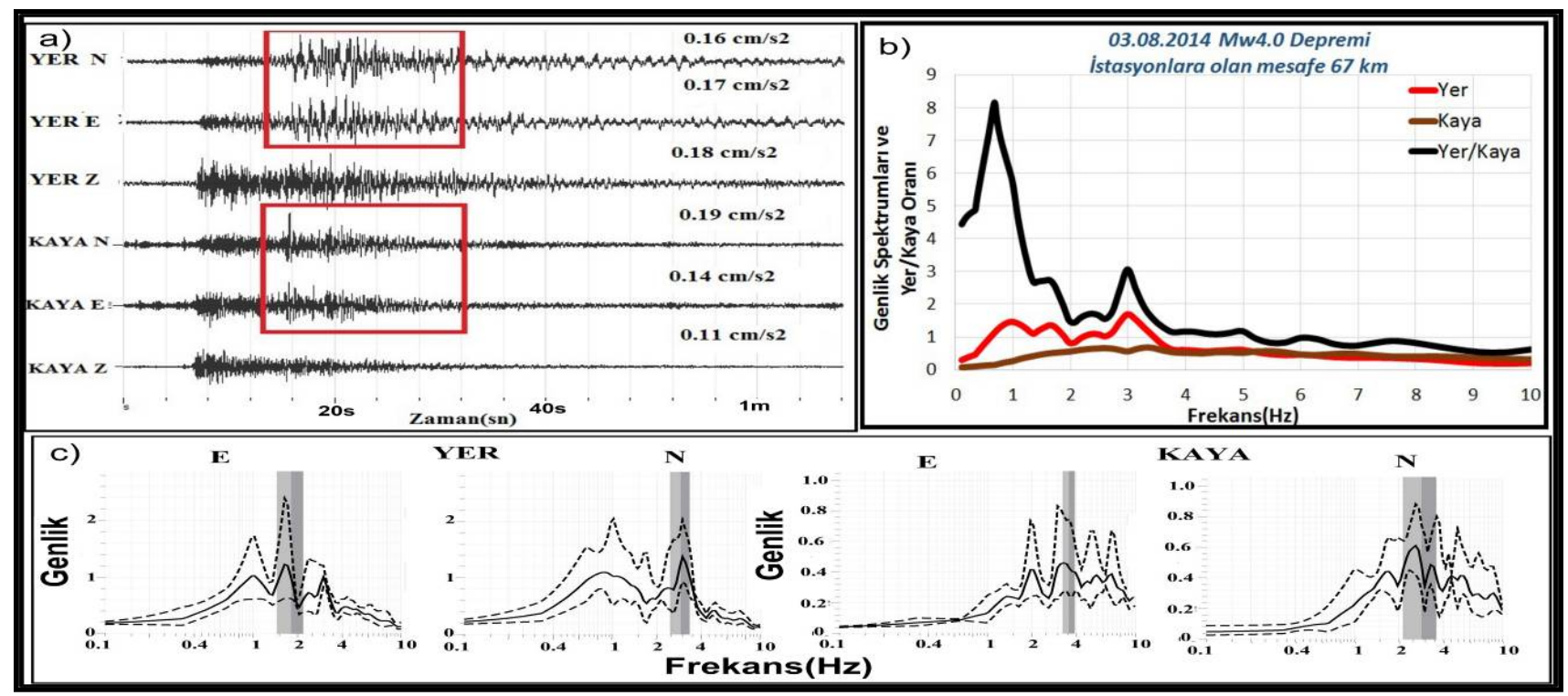

Şekil 15. a) 03.08.2014 Depremi Mw4.0 deprem kaydı ve seçilen S fazı, b) Yatay spektrumların bileșkesi ve yer/kaya oranı, c) Yer ve kaya yatay bileşen spektrumları

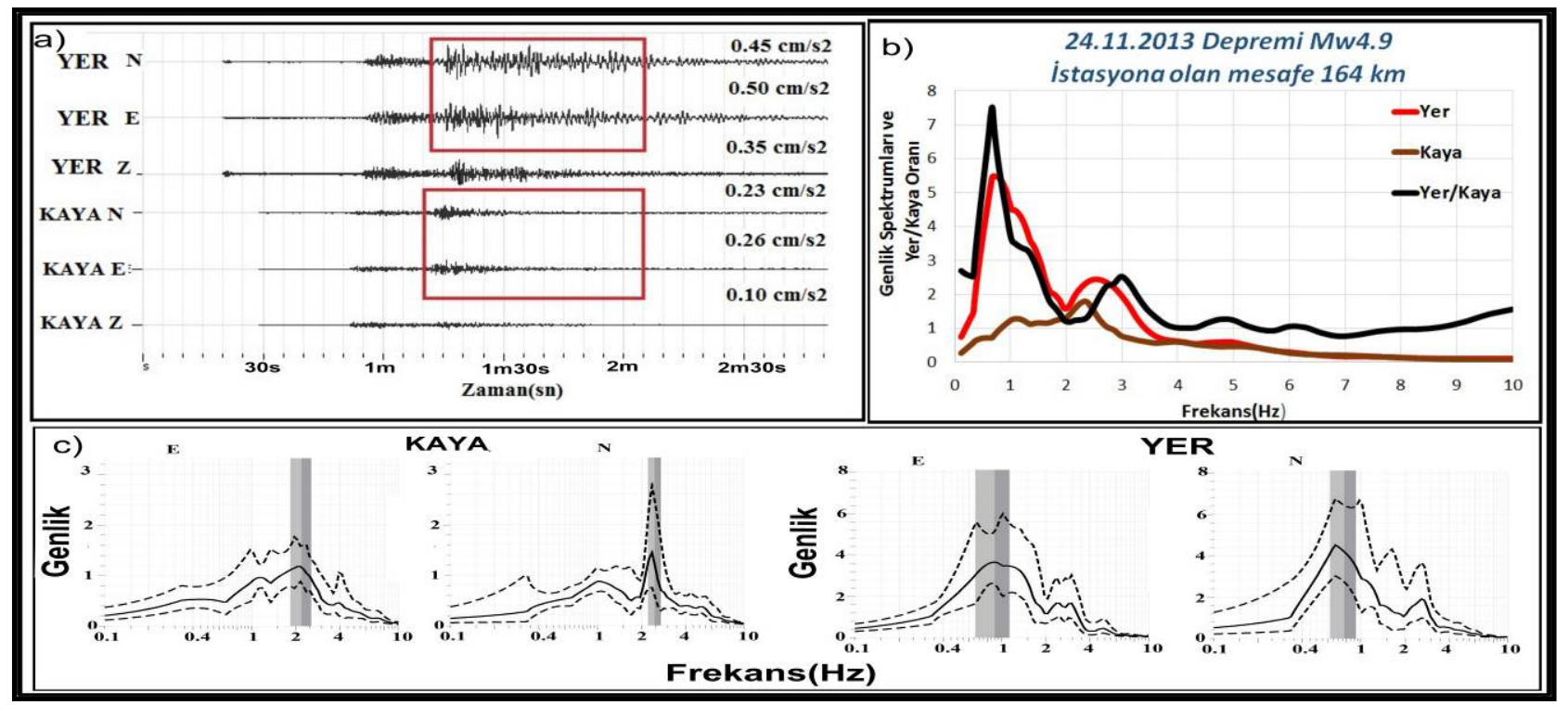

Șekil 16. a) 24.11.2013 Mw 4,9 deprem kaydı ve seçilen S fazı, b) Yatay spektrumların bileșkesi ve yer/kaya oranı, c) Yer ve kaya yatay bileşen spektrumları 


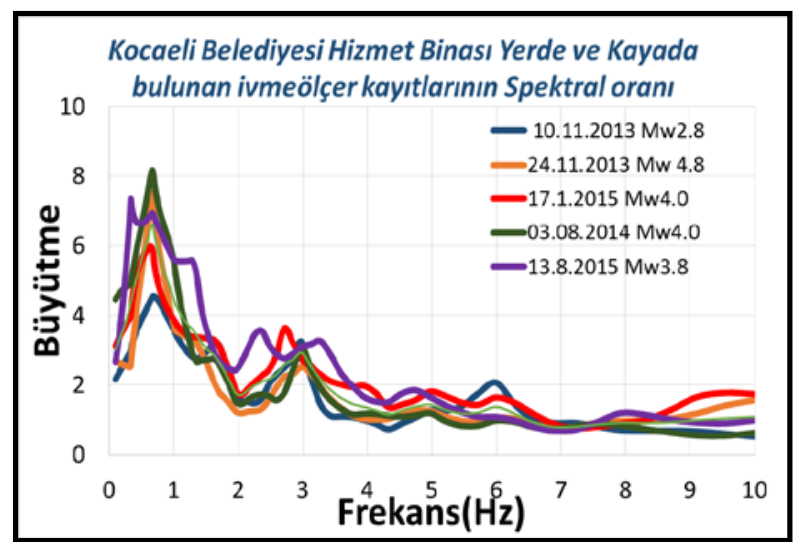

Şekil 17. Yerde ve kayada kaydedilen 5 adet deprem kaydının spektral oran yöntemine (SSR) göre değerlendirilmesi

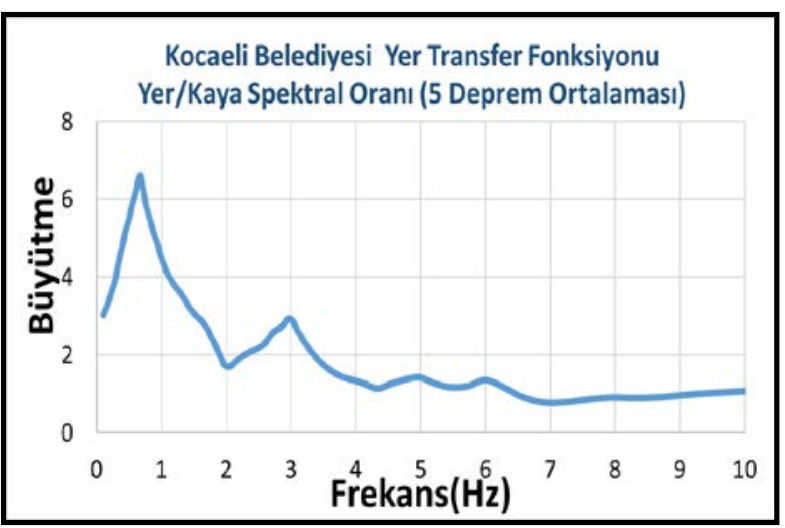

Şekil 18. Yer büyütmesi için SSR yöntemi sonuçlarının ortalaması

\subsubsection{Yatay/Düssey spektral oran yöntemi}

Depremde kaydedilen ivme kayıtları ile büyütme ve baskın frekans hesaplamasında iki adet yatay bileșen spektrumunun düşey bilesene spektrumu spektral oran (HVSR) yöntemi kullanılmıştır. Kullanılan depremler yer ve binada kaydedilen 16 adet deprem olup Tablo 1'de verilmiștir. Her bir istasyon tarafından kaydedilen depremlerin 3 bileșene ait spektral oranları hesaplandıktan sonra yatay bileșenlerin ortalaması, düșey bileșene oranlanmıştır. Şekil 19-22'de örnek olarak 4 adet deprem kaydı gösterilmiştir.

Büyütme analizi için deprem kayıtlarının yalnızca S dalga penceresi kullanılmıştır. Her kayıt için uygulanan ișlemler tamamen aynı olup, 0,1-20 $\mathrm{Hz}$ arasinda Butterworth, Band-Pass pencereleme uygulanmış, veri başına ve sonuna \%5 kosinüs fonksiyonu ile yuvarlatıldıktan sonra FFT ile spektrumları hesaplanmıştır, daha sonra spektrumlara yuvarlatma (Konno ve Ohmachi, b=40) işlemi yapılmıştır [29].

Yöntemin, hareketin düşey bileşeninin yerel jeolojiden etkilenmediği varsayımı nedeniyle, bulacağımız değer, bize o istasyona ait büyütme ve baskın frekans değerini verir. Her bir istasyon için spektral oran ve büyütme değeri hesaplanmıștır. $\mathrm{Bu}$ spektral oran ve büyütme değerlerinin geometrik ortalaması alınarak her bir istasyon için tek bir yer büyütme fonksiyonu ve baskın frekans değeri elde edilmiştir. Kullanılan veri işlem aşamaları aşağıda belirtilmiştir.

-- Eğilim etkisi giderimi

-- Filtreleme işlemi (Band pass, 0,1-20 Hz)

-- Pencereleme işlemi

-- Törpüleme işlemi (taper, \%5)

-- Hızlı Fourier Dönüșümü (FFT)

-- Yuvarlatma ișlemi (Konno ve Ohmachi, $b=40$ )

--Yatay/Düşey oranı hesabı

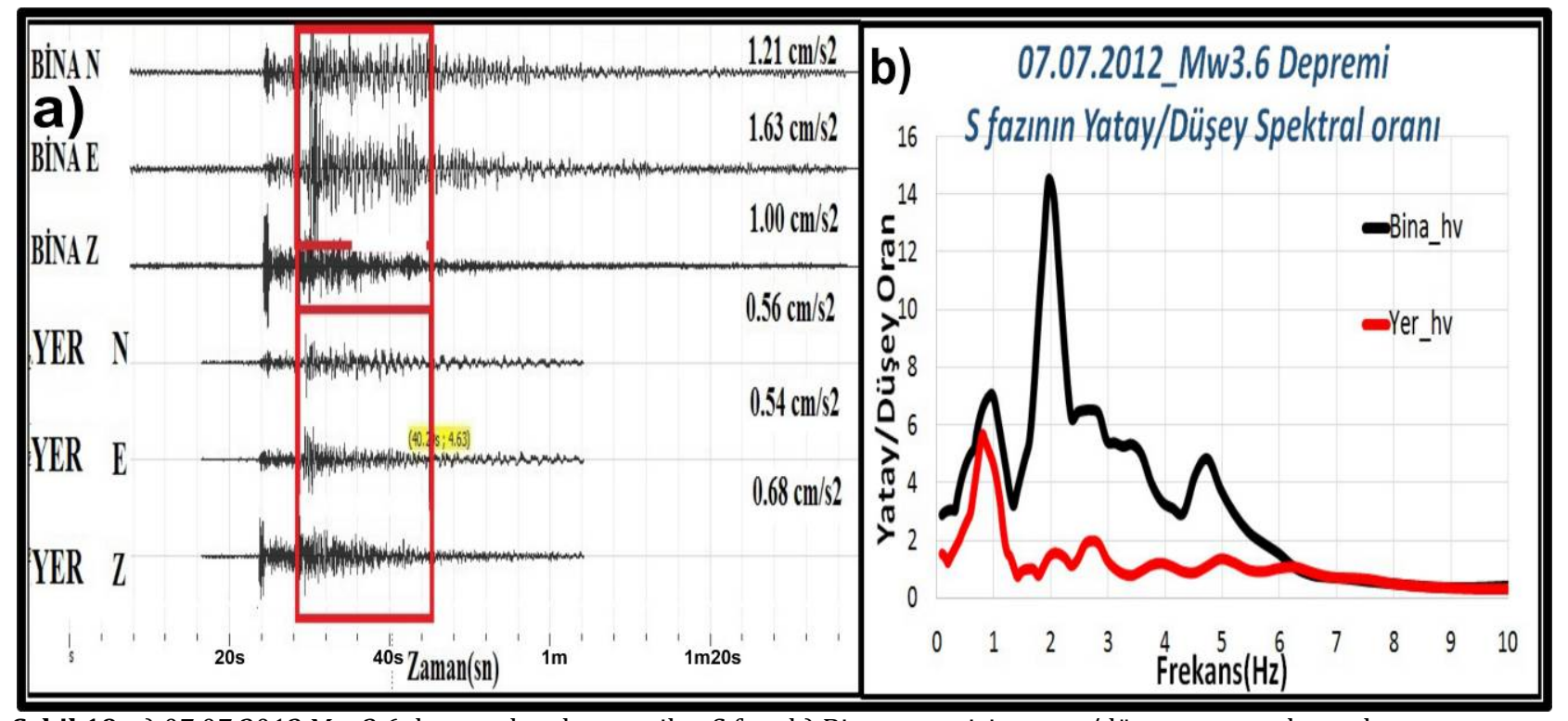

Şekil 19. a) 07.07.2012 Mw 3,6 deprem kaydı ve seçilen S fazı, b) Bina ve yer için yatay/düşey oran spektrumları 


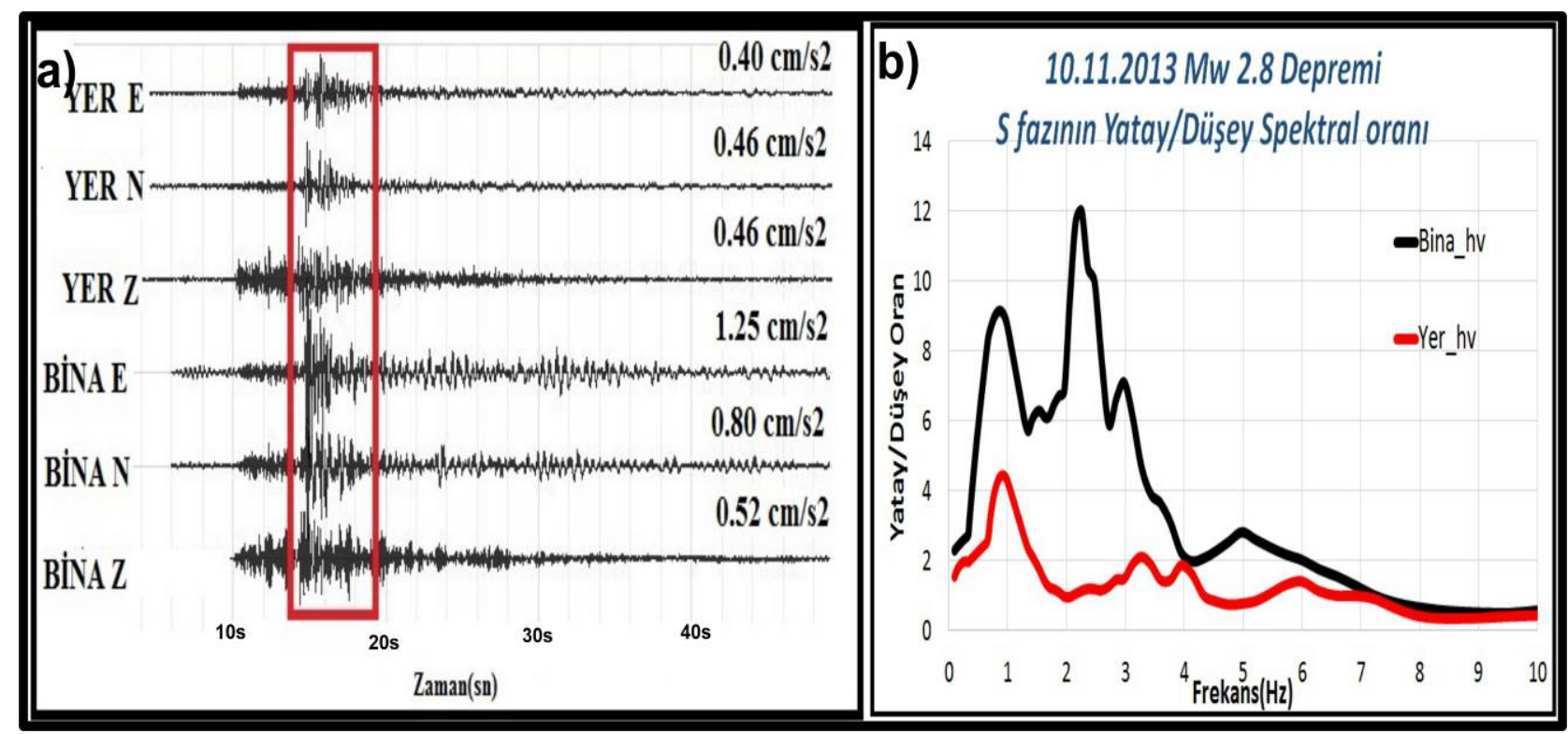

Şekil 20. a) 10.11.2013 Mw 2,8 deprem kaydı ve seçilen S fazı, b) Bina ve yer için yatay/düşey oran spektrumları

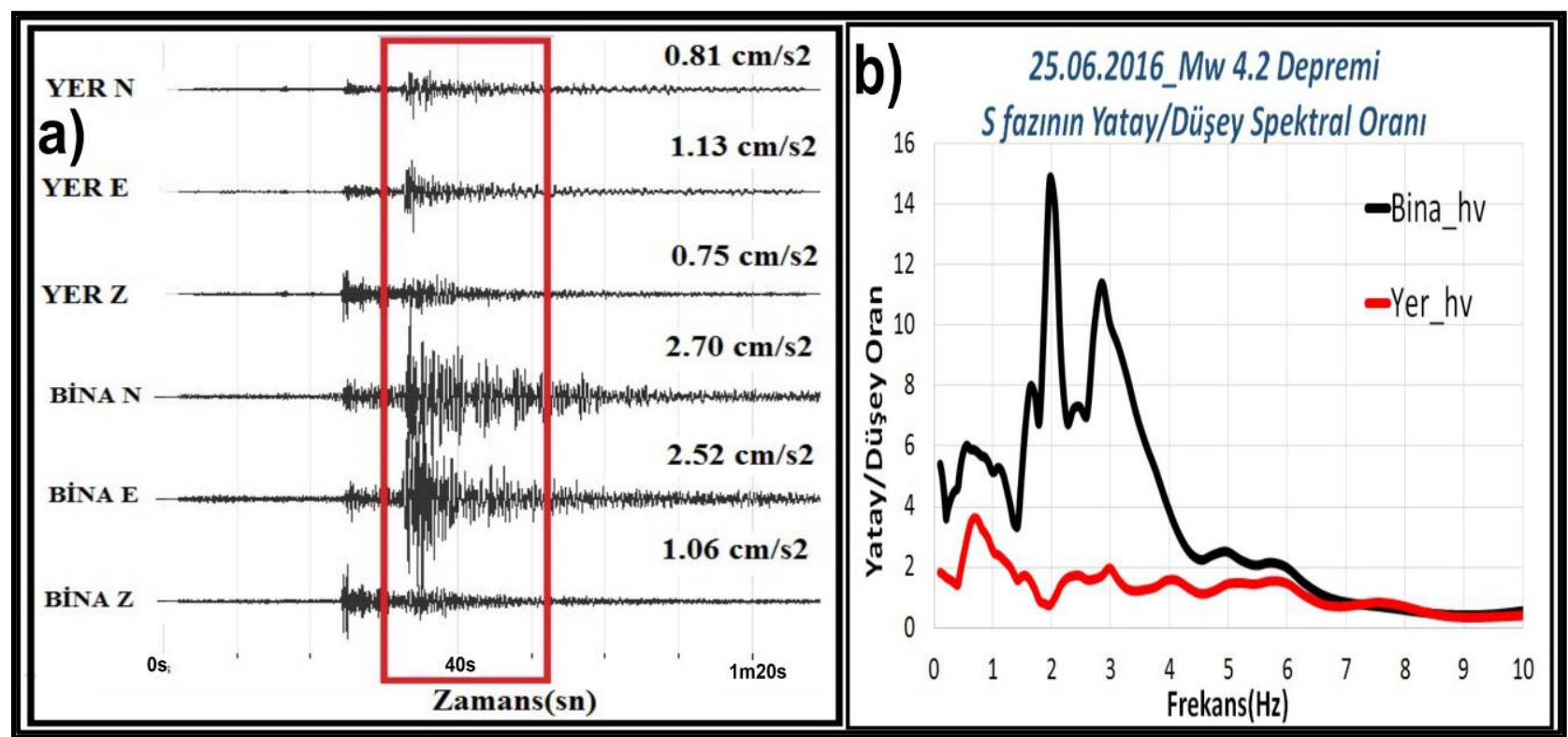

Şekil 21. a) 25.06.2016 Mw 4,2 deprem kaydı ve seçilen S fazı, b) Bina ve yer için yatay/düşey oran spektrumları

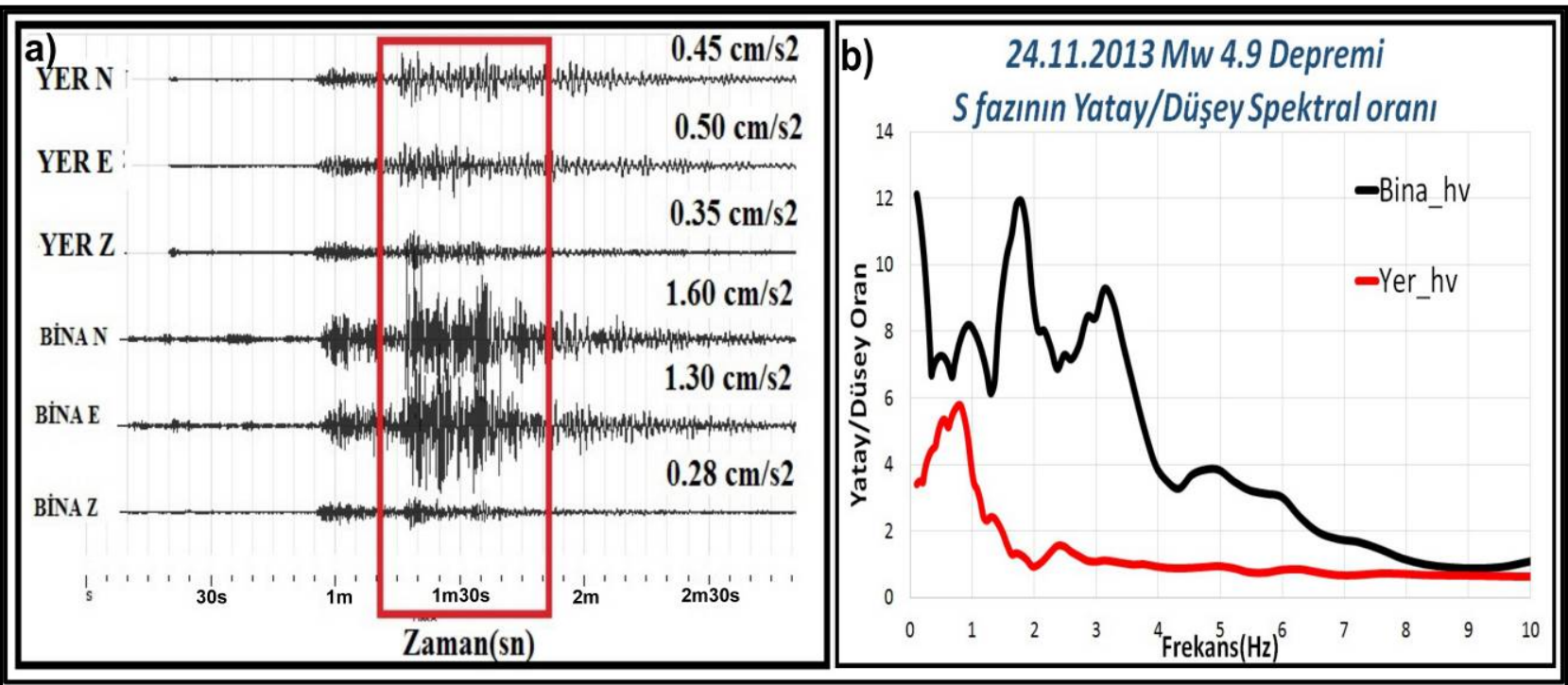

Şekil 22. a) 24.11.2013 Mw 4,9 deprem kaydı ve seçilen S fazı, b) Bina ve yer için yatay/düşey oran spektrumları 
Şekil 19-22'de görülen dört adet grafikte, a da bina ve yerde kaydedilen deprem kayıtları ve seçilen $\mathrm{S}$ fazı, $\mathrm{b}$ de ise Seçilen $S$ fazında yatay bileşenlerin düşey bileşenlere oranlanması sonucu binada ve yerde hesaplanan transfer fonksiyonu görünmektedir. Şekil 23 ' te ise 16 adet deprem sonuçlarını görmekteyiz.

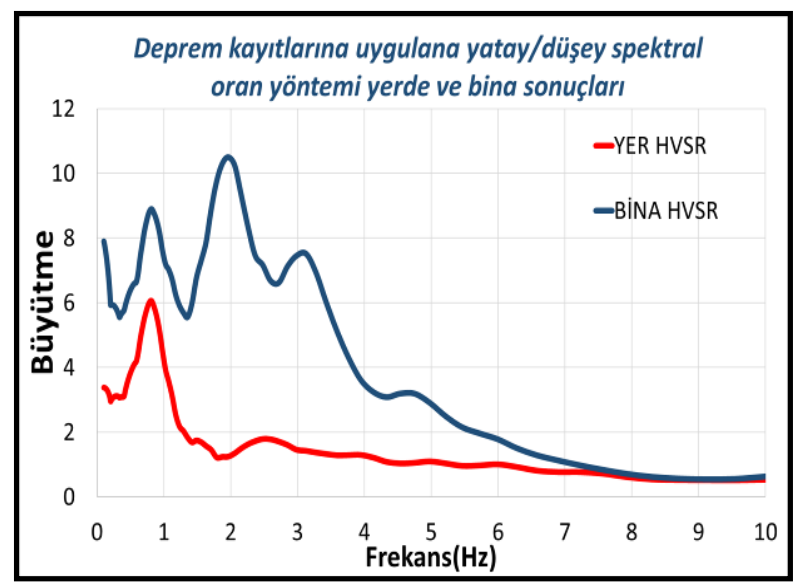

Şekil 23. HVSR yöntemine göre ortalama yer ve bina büyütmeleri

Deprem kayıtlarının S fazının uygulanan HVSR (yatay/düşey spektral oran) yönteminin Şekil 23'de verilen sonuçlarına bakıldığında yer baskın salınım frekansı $0,8 \mathrm{~Hz}$ büyütme değeri ise yaklaşı 6 civarında hesaplanmıştır. Bina sonuçlarına baktığımız zaman ise $2 \mathrm{~Hz}$ frekansinda net bir keskin doruk noktası görülmektedir. Ayrıca yapı transfer fonksiyonunda $0,8 \mathrm{~Hz}$ frekansinda bir doruk görünmekte olup bu doruk yer etkisi olarak yorumlanmıștır. Şekil 23'de görüldüğü üzere $0,8 \mathrm{~Hz}$ frekansında hem binada hem de yerde baskın doruklar görülmüştür. Bu etkinin binanın temelinin şerit temel olmasından kaynaklanması düşünülmektedir. Bina büyütme değeri ise bu yöntemde diğer yöntemlere göre daha fazla çıkmış olup bunun sebebi binanın düşey bileşenindeki spektrumların değerlerinin düşük olmasından kaynaklanmaktadır.

\subsection{Bina yer girişim durumu}

Yapılan analizler sonucunda doğal yer baskın salınım frekansı yaklaşık $0,8 \mathrm{~Hz}$, titreşim periyodu $1.25 \mathrm{sn}$, bina frekansı $2 \mathrm{~Hz}$, titreşim periyodu ise 0,5 sn olarak hesaplanmıștır. Kocaeli Belediyesi Hizmet binasının girişim durumunu incelemek amacıyla 2 adet çalışma yapilmıştır.

Birinci analizde söz konusu bina eski esnek bina olduğundan sertlik değeri $C=0,1$ veya $C=0,12$ alınabilir. Bu değerlere göre;

$$
\begin{aligned}
& \mathrm{Ta}=0.5 \mathrm{~T} \\
& \mathrm{~Tb}=1.5 \mathrm{~T}
\end{aligned}
$$

$$
\begin{gathered}
\mathrm{T}_{\mathrm{a}}=0.5 * 1.25=0.625 \mathrm{sn} \text { ve } \mathrm{T}_{\mathrm{b}}=1.5 * 1.25=1.875 \mathrm{sn} \\
\mathrm{N} 1=\mathrm{Ta} / \mathrm{C} \\
\mathrm{N} 2=\mathrm{Tb} / \mathrm{C}
\end{gathered}
$$

$\mathrm{N}_{1}=(0.625 / 0.10)=6.25$ ve N2=(1.875/0.10) $=18.75$ olarak bulunmuştur. Burada Ta, alt periyod ve $\mathrm{Tb}$, üst periyod değeridir. Söz konusu bölgede $\mathrm{N}_{1}=6.25$, $\mathrm{N}_{2}=18.75$ kat adetleri arsında girişim bölgesinde yer olanlarda girişim hasarı olacağı düşünülmüștür. Hizmet binası 5 katlı olması dolayısıyla girişim bölgesi dışında kaldığı düşünülmektedir.

İkinci analizde [14] tarafından önerilen denklem kullanılmıştır. Bu sistemde bina spektrumunun yer spektrumu arasındaki oranlar kullanılarak girişim tehlike seviyeleri belirlenmiştir. Bu tehlike seviyeleri 3 gruba ayrılmıştır. Yüksek seviye, oran değeri <\% 15 (bina frekansı ile yer arasındaki fark) olduğunda, orta seviye, oran değeri\% 15-25 olduğunda ve oran $>\% 25$ olduğunda düşük seviyededir.

Serbest alan frekansımız $0,8 \mathrm{~Hz}$ bina baskın frekansımız $2 \mathrm{~Hz}$ olması sebebi ile bina ve yer arasındaki frekans farkı $>25$ den fazla olması sebebi ile girişim çekincesinin düşük olduğunu söyleyebiliriz.

Yapılan iki analiz sonucunda binanın girişim bölgesi dışında kaldığı düşünülmektedir.

\subsection{Bina sönüm oranı}

Sönüm oranı yer ve yapılar için önemli bir dinamik parametredir. Sönüm arttıkça yapıya gelen deprem yükü azalabilir. H/V spektrumundan yarı-güç band genişliği (Half-Power Bandwidth) yöntemiyle elde edilir.

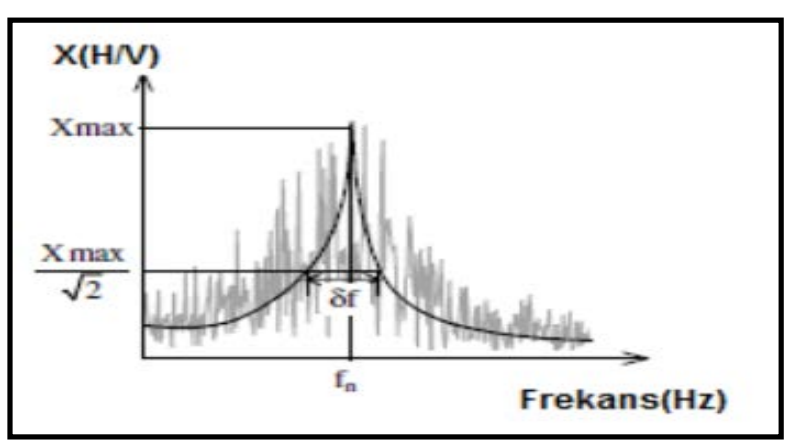

Şekil 24. Sönüm oranı hesaplama yöntemi

Sönüm oranı, yarı-güç band genişliği yöntemiyle belirlenen değerlerin aşağıdaki formülde yerlerine yazılmasıyla hesaplanır.

$$
\delta_{n}=\frac{1}{2} \times \frac{\delta_{f}}{f_{n}}
$$


Burada $\delta$ n Sönüm oranı fn yapının baskın salınım frekansını ifade eder. Kocaeli Büyükşehir Belediyesi binasında bulunan ivmeölçer istasyonu verilerinin sonucunda Kocaeli Belediyesi hizmet binasının sönüm oranı \%12 olarak hesaplanmıştır.

\subsection{Deprem kayıtları analizlerinin karşılaştırılması}

Bina ve yerde bulunan ivmeölçer istasyonlarının kaydettiği ivme kayıtları SSR ve HVSR yöntemlerine göre değerlendirilmiș baskın salınım frekansları ve büyütme değerleri bulunmuştur.

Binada yapılan çalışmalarda (deprem kayıtlarının iki farklı yöntemle değerlendirilmesi) yaklaşı $2 \mathrm{~Hz}$ frekansında büyütmeler tespit edilmiş olup bunun bina frekansı olduğu düșünülmektedir. Bu frekansta SSR yöntemi değerlendirilmesi sonucu büyütme değeri yaklaşık olarak 8 kattır. Ancak deprem kayıtlarının S fazı kullanılarak HVSR tekniğinin çıktılarına baktığımızda aynı frekansta büyütme değerinin 10 kat olduğunu görebiliyoruz.

Şekil 25'te bina içerisinde yapılan tüm çalışmaların sonuçları sunulmuş olup, tüm yöntemlerde bina frekansı $2 \mathrm{~Hz}$ olarak bulunmuştur. Binada deprem kayıtlarının yatay/düşey spektral oran tekniğine göre değerlendirilen kayıtların tamamında 0,8 $\mathrm{Hz}$ civarında yer etkisi gözlenmiş olup bu etki SSR tekniğinde bulunmamaktadır. Bunun sebebi bina kayıtlarından yer etkisinin giderilmesidir. $\mathrm{Bu}$ nedenden dolayı binada $0,8 \mathrm{~Hz}$ frekansındaki bu doruk noktasının yer etkisi olarak değerlendirilmiştir. Sonuçlar Tablo 3'te gösterilmeye çalışılmıştır.
Yerde yapılan çalışmalarda yer baskın salınım frekansı 0.77-0.81 (Ortalama 0,8) Hz civarında tespit edilmiş olup büyütme değerleri yaklaşık 6 kattır. SSR yöntemini uygulamanın sonucunda bulunan frekans değeri diğer yöntemlerde bulunan baskın frekanstan çok az farklıdır. Sonuçlar Tablo 4'te gösterilmeye çalışılmıştır.

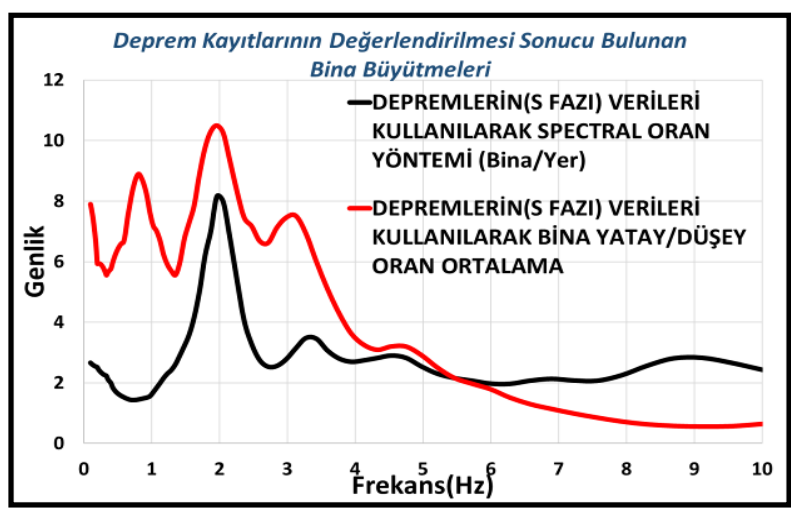

Şekil 25. Binada kullanılan yöntemlerin karşılaştırılması

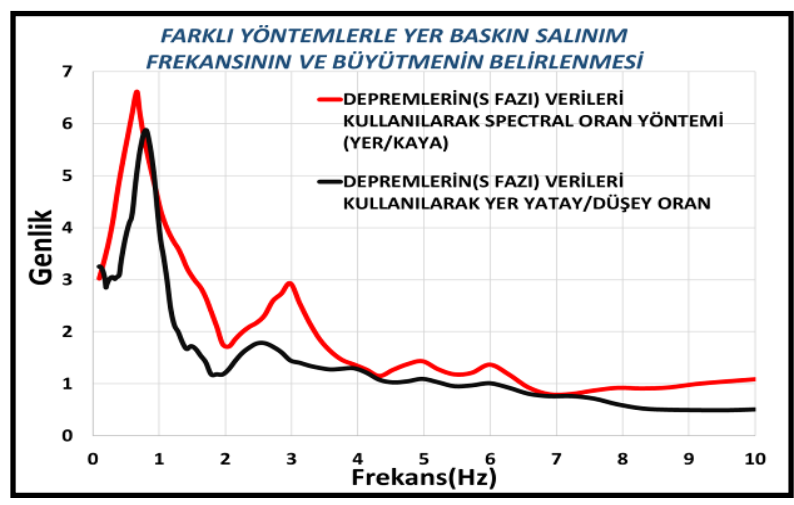

Şekil 26. Yerde yapılan SSR ve HVSR yöntemlerin sonuçlarının karşılaştırılması

Tablo 3. Bina büyütmesi için kullanılan yöntemlerin (SSR ve HVSR) sonuçları

\begin{tabular}{|c|c|c|c|c|c|c|c|}
\hline $\mathbf{M w}$ & $\begin{array}{c}\text { Uzaklı } \\
\mathbf{( k m )}\end{array}$ & $\begin{array}{c}\mathbf{f} \\
\mathbf{( H z )}\end{array}$ & $\begin{array}{c}\mathbf{T}_{\mathbf{0}} \\
\mathbf{( s n )}\end{array}$ & $\begin{array}{c}\text { Bina/Yer } \\
\text { büyütmeleri }\end{array}$ & $\begin{array}{c}\mathbf{f} \\
\mathbf{( H z})\end{array}$ & $\begin{array}{c}\mathbf{T}_{\mathbf{0}} \\
\text { (sn) }\end{array}$ & $\begin{array}{c}\text { H/V } \\
\text { büyütmeleri }\end{array}$ \\
\hline 4,4 & 147 & 2,05 & 0,49 & 8,8 & 2,15 & 0,47 & 8,5 \\
\hline 4,2 & 15 & 1,96 & 0,51 & 6,2 & 1,96 & 0,51 & 14 \\
\hline 4,7 & 69 & 2,05 & 0,49 & 12,6 & 2,05 & 0,49 & 12,3 \\
\hline 6,2 & 195 & 1,78 & 0,56 & 8,8 & 1,78 & 0,56 & 11,5 \\
\hline 5,3 & 184 & 2,05 & 0,49 & 7,2 & 2,05 & 0,49 & 9,6 \\
\hline 3,6 & 40 & 2,05 & 0,49 & 5,6 & 2,05 & 0,49 & 14 \\
\hline 5,6 & 386 & 1,87 & 0,53 & 6,7 & 1,96 & 0,51 & 11,2 \\
\hline 2,8 & 30 & 1,7 & 0,59 & 6 & 2,05 & 0,49 & 12 \\
\hline 4,9 & 164 & 1,96 & 0,51 & 10 & 1,96 & 0,51 & 12 \\
\hline 4,5 & 41 & 1,87 & 0,53 & 11,2 & 1,7 & 0,59 & 11 \\
\hline 4 & 105 & 1,96 & 0,51 & 9,4 & 1,96 & 0,51 & 15 \\
\hline 4,3 & 86 & 2,05 & 0,49 & 10 & 1,96 & 0,51 & 11,9 \\
\hline 4,2 & 61 & 2,05 & 0,49 & 7,4 & 1,96 & 0,51 & 14 \\
\hline 3,5 & 18 & 1,96 & 0,51 & 8 & 2,15 & 0,47 & 9 \\
\hline 5,1 & 286 & 1,96 & 0,51 & 8,4 & 1,87 & 0,53 & 11,4 \\
\hline 6,2 & 372 & 2,05 & 0,49 & 6,3 & 1,96 & 0,51 & 9,7 \\
\hline Ortalama & & $\mathbf{1 , 9 6}$ & $\mathbf{0 , 5 1}$ & $\mathbf{8 , 3}$ & $\mathbf{1 , 9 7}$ & $\mathbf{0 , 5 1}$ & $\mathbf{1 1 , 6}$ \\
\hline
\end{tabular}


Tablo 4. Yer büyütmesi için kullanılan yöntemlerin (SSR ve HVSR) sonuçları

\begin{tabular}{|c|c|c|c|}
\hline Yöntem & $\mathbf{f}(\mathbf{H z})$ & $\mathbf{T}_{\mathbf{0}}(\mathbf{s n})$ & Büyütme \\
\hline SSR & 0,8 & 1,25 & 6 \\
\hline HVSR & 0,7 & 1,42 & 6,5 \\
\hline
\end{tabular}

\section{Sonuçlar}

Kocaeli Belediyesi hizmet binasına ve bahçesine yapı sağlığı izleme amacıyla kurulan iki sabit ivmeölçer aygıtının kaydettiği deprem (ivme kaydı) kayıtlarının farklı yöntemlerle (SSR, HVSR) değerlendirilmiş, yer ve binaya ait büyütme oranı ve baskın salınım frekansları belirlenmiştir.

Yapının inşa edildiği yere kurulan ivmeölçer istasyonunun yer sinıfının belirlenmesi amacıyla yapılan MASW etüdünden elde edilen $\mathrm{Vs}_{30}=147 \mathrm{~m} / \mathrm{s}$ ve NERHP sınıflamasına göre yer sınıfı yumuşak topraklar (E) olarak elde edilmiştir. Vs ve Vs 30 kullanılarak yerin baskın salınım periyodu 1,25 ve 1,23 sn olarak belirlenmiştir. Benzer değerler SSR ya da HVSR yöntemlerinin sonucunda da elde edilmiştir. Ayrıca yerin alt ve üst periyodları 0,625 sn ve 1,875 sn olarak belirlenmiştir.

SSR ve HVSR yöntemlerinin ortak sonucu olarak bina baskın salınım frekansı $2 \mathrm{~Hz}$ (periyot 0,5 sn) olarak belirlenmiştir. Bu durum, iki yönteminde yer-yapı etkileşim çalışmalarında kullanılabileceğini göstermektedir. Ayrıca bu çalışmada 5 katlı yapı için bulunan binanın baskın salınım frekansı, rezonans açısından yer frekansı ile karşılaştırıldığında yerin alt ve üst frekanslarının dışında kaldığı için uygun bir frekans olduğu düşünülmektedir.

Büyütmelerde özellikle deprem kayıtlarının S fazlarına uygulanan HVSR yönteminde SSR yöntemine göre daha yüksek doruk değerleri gözlenmiştir. Deprem kayıtlarının $S$ fazlarının tek istasyon yöntemine göre değerlendirilmelerinde 0,8 $\mathrm{Hz}$ frekansında yer etkisi gözlenmiş olup, SSR yönteminde binanın inşa edildiği yer, referans istasyon olarak kullanıldığından dolayı bu etki giderilmiș ve saf bina frekansı elde edilmiștir. Binada yer frekans etkisinin HVSR yönteminde doğrudan görülmesinin sebebi bina temelinin radye temel olmamasından kaynaklandığı düşünülmektedir.

SSR ve HVSR yöntemlerinin sonuçlarına göre yakın depremlerde depremin büyüklüğüne bağlı olarak daha büyük bina büyütmesi elde edilmiştir. Fakat depremin büyüklügüne ve uzaklığına bağlı bina baskın salınım periyodunda önemli bir değişiklik görülmemektedir.

$\mathrm{Bu}$ çalışmada da görüleceği üzere binanın statik projesinde belirtilen bina baskın salınım periyodunun uygun yapılıp yapılmadığı ve bina tepkisinin belirlenmesinde deprem kayıtlarının analizlerinin uygun sonuçlar verdiği belirlenmiştir. $\mathrm{Bu}$ çalışmanın sonuçlarına göre 2 farklı yöntemde (SSR ve HVSR) yer-yapı etkileşimi çalışmalarında baskın salınım periyodunda etkili olarak kullanılabileceğini ancak bina büyütme değerinde SSR yönteminin daha doğru sonuç verdiği düşünülmektedir.

Yeni Deprem yönetmeliği ile yüksek yapılara kurulacak olan yapı sağlığı izleme sistemlerinin yapılar hakkında vereceği bilgilerin ne kadar önemli olduğu görülmektedir. Ayrıca bu sistemlerde yapının yanında inşa edildiği yer koşullarına ivmeölçer kurulması gerekmektedir.

\section{Teşekkür}

Çalışmada kullanılan ivmeölçer aygıtlarının kurulması, sürekli olarak çalıştırılması ve verilerinin sorunsuz kaydedilmesini sağlayan Kocaeli Büyükșehir Belediyesi Zemin ve Deprem Şube Müdürlüğü çalıșanlarına ve Bașbakanlık Afet ve Acil Durum Yönetimi Başkanlığı(AFAD), Deprem Dairesi Başkanlığı Türkiye Kuvvetli Yer hareketi ve Ön hasar Tahmin Sistemleri Çalışma Grubu çalışanlarına sonsuz teşekkür ederiz.

\section{Kaynakça}

[1] Irikura, K., Iwata, T., Sekiguchi, H., Pitarka, A.,1996. Lessons from the 1995 Hyogo-Ken Nanbu earthquake: why where such destructive motions generated to buildings? Journal of Natural Disaster Science, 17(2), 99-127.

[2] Borcherdt R. D., 1970. Effects of Local Geology on Ground Motion Near San Francisco Bay. Bulletin of The Seismological Society of America, 60, 29-61.

[3] Steidl J. H., Tumarkin A. G., Archuleta R. J., 1996. What is a reference side? Bull Seism. Soc. Am., $86,1733-1748$.

[4] Nakamura Y., 1989. A Method for Dynamic Characteristics Estimation of Subsurface Using Microtremor on the Ground Surface. Quarterly Report of the Railway Technical Research Institute, 30(1), 25-33.

[5] Lermo J., Chavez G. F. J., 1993. Site Effect Evaluation Using Spectral Ratios with Only One Station. Bulletin Seismological Society of America, 83, 1574-1594.

[6] Yalçınkaya, E., Alptekin, Ö., 2003. Dinar'da zemin büyütmesi ve 1 Ekim 1995 depreminde gözlenen hasarla ilişkisi. Hacettepe Üniversitesi, Yerbilimleri Uygulama ve Araştırma Merkezi Bülteni,27,1-13.

[7] Gök E., Keçecioğlu M., Çeken U., Polat O., 2012. İzmirnet İstasyonlarında Standart Spektral Oran Yöntemi Kullanılarak Zemin Transfer 
Fonksiyonlarının Hesaplanması. Dokuz Eylül Üniversitesi, Mühendislik Fakültesi, Mühendislik Bilimleri Dergisi, 14(41), 1-11.

[8] Uyanık O., Çatlığlu B., Uyanık NA., Öncü Z., Sabbağ N., 2012a. Kentsel Dönüşüm Projelerinde Betonarme Yapıların Beton Kalitesinin Sismik Ultrasonik Hızlardan Belirlenmesi. 1.Yerbilimleri Sempozyumu, 18-20 Ekim, Isparta, 147-151.

[9] Uyanık O., Sabbağ N., Çatlığlu B., Uyanık NA., Öncü Z., 2012b. Sismik Ultrasonik Hızlardan Kayaçların Kırıklılık Ve Fissür İndekslerinin Belirlenmesi. 1. Yerbilimleri Sempozyumu, 1820 Ekim, Isparta, 159-164.

[10] Uyanık O., Çatlığlu B., Sabbağ N., Öncü Z., Uyanık NA., 2012c. Kayaçların Fiziksel Özellikleri İle Sismik Ultrasonik Hızlar Arasındaki İlişkilendirmeler. 1. Yerbilimleri Sempozyumu, Isparta, 165-169.

[11] Sabbağ N., Uyanık O., 2017. Prediction of Reinforced Concrete Strength by Ultrasonic Velocities. Journal of Applied Geophysics, 141, 13-23.

[12] Sabbağ, N., Uyanık, O, 2018. Determination of the reinforced concrete strength by electrical resistivity depending on the curing conditions, Journal of Applied Geophysics, 155, 13-25.

[13] Karabulut, S., Ozel O., Özçep F., 2009. Deprem Tehtidi Altındaki Mühendislik Yapılarının Hakim Titreşim Periyotlarının Belirlenmesinde Yeni Bir Seçenek: Mikrotremor Yöntemi Ve Örnek Uygulaması. New World Sicence Academy, 4(3), 428-441

[14] Gosar, A., Roser, J., Sket Motnikar, B. Zupansis, P. 2010. Microtremor study of side effects and soilstructure resonance in the city of Ljubljana (central Slovenia). B. Earthq. Eng., 8, 571-592.

[15] Uyanık O., 2014. Jeofizik ve Klasik Yöntemlerle Yapı İncelemeleri (Yapı Jeofiziği). JFMO Eğitim Yayınları No:19, s: 80, ISBN:978-605-01-06435.

[16] Timur E., Ozicer S., Sari C., Uyanik O.. 2015. Determination of Buildings Period and Vulnerability Index Using Microtremor Measurements. 8th Congress of the Balkan Geophysical Society (EAGE) 5-8 October 2015, Chania, Greece.

[17] Öziçer S. 2016. Jeofizik Yöntemler ile Riskli Yapıların Belirlenmesi ve İzmir Örneği. SDÜ Fen Bilimleri Enstitüsü Jeofizik Müh. Anabilim dalı. s:93.
[18] Öziçer S., Uyanık O., Timur E., 2017. Investigation of Period and Resonance Risk of Buildings with Various Heights Using Microtremor Method. 9th Congress of the Balkan Geophysical Society 5-9 November 2017, Antalya, Turkey

[19] Özmen, B., 2000, 17 Ağustos 1999 İzmit Körfezi Depreminin Hasar Durumu (Rakamsal Verilerle), TDV/DR 010-53, Türkiye Deprem Vakfi, 132 s.

[20] McMechan, G.A., Yedlin, M.J., 1981. Analysis of dispersive waves by wave field transformation. Geophysics 46, 869-874.

[21] Gabriels, P., Snieder, R., Nolet, G., 1987. In situ measurement of shear wave velocity in sediments with higher-mode Rayleigh waves. Geophysical Prospecting 35, 187-196.

[22] Tselentis, G.-A., Delis, G., 1998. Rapid assessment of $\mathrm{S}$-wave profiles from the inversion of multichannel surface wave dispersion data. Annali di Geofisica 41 (1), 1-15.

[23] Park, C.B., Miller, R.D., Xia, J., 1999. Multi-channel analysis of surface waves. Geophysics 64 (3), 800-808.

[24] Dorman, J., Ewing, M., 1962. Numerical inversion of seismic surface wave dispersion data and crust-mantle structure in the New YorkPennsylvania area. Journal of Geophysical Research 67, 5227-5241.

[25] Uyanık, O., Ekinci B., Uyanık N.A. (2013). Liquefaction analysis from seismic velocities and determination of lagoon limits Kumluca/Antalya example. Journal of Applied Geophysics 95 (2013) 90-103

[26] Uyanık, O., 2015. Deprem Ağır Hasar Alanlarının Önceden Belirlenmesi ve Şehir Planlaması için Makro ve Mikro Bölgelendirmelerin Önemi. Süleyman Demirel Üniversitesi, Fen Bilimleri Enstitüsü Dergisi, 19(2), 24-38.

[27] Pitilakis, K., 2004, "Site Effects, Recent Advances in Earthquake Geotechnical Engineering and Microzonation", Ansal (Ed), Kluwer Academic Publishers, Dordrecht, the Nederland, 354p

[28] Sesame, 2004. Guidelines for the Implementation of the $\mathrm{H} / \mathrm{V}$ Spectral Ratio Technique on Ambient Vibrations, Measurements Processing and Interpretation.

[29] Konno K., Ohmachi T., 1998. Ground-Motion Characteristics Estimated from Spectral Ratio between Horizontal and Vertical Components. Bulletin of the Seismological Society of America, $88,1,228-241$. 